\title{
Experimental Investigation of Combined LNT + SCR Diesel Exhaust Aftertreatment
}

\author{
Thomas Wittka - Bastian Holderbaum • Peter Dittmann • \\ Stefan Pischinger
}

Received: 30 September 2014 / Accepted: 26 January 2015 / Published online: 13 February 2015

(C) Springer SIP, AG 2015

\begin{abstract}
In the present work, an exhaust aftertreatment system combining lean $\mathrm{NO}_{\mathrm{X}}$ trap (LNT) plus exhaust bypass, passive selective catalytic reduction catalyst (SCR) and engine-independent LNT reductant supply by onboard exhaust fuel reforming was developed. Further, it was experimentally investigated in steady-state operation on an engine test bench and on road in a demonstrator vehicle. The intrinsic $\mathrm{NH}_{3}$ formation during the LNT regeneration was intensively studied as one key function for passive SCR without active urea dosing. LNT regeneration duration and temperature are the most significant parameters for $\mathrm{NH}_{3}$ emission. In steadystate operation, the passive SCR could be forced to a contribution to the total $\mathrm{NO}_{\mathrm{X}}$ conversion of up to $35 \%$. At $170{ }^{\circ} \mathrm{C}$, $50 \%$ steady-state total $\mathrm{NO}_{\mathrm{X}}$ conversion was achieved, and at $250{ }^{\circ} \mathrm{C}$ and a fuel consumption penalty of $<2 \%$, complete $\mathrm{NO}_{\mathrm{X}}$ conversion could be demonstrated. Compared to conventional LNT operation with frequent engine enrichment, the engine-independent LNT regeneration with reformate gas is energetically more efficient and advantageous regarding $\mathrm{CO}_{2}$ emissions. Additionally, by shifting $\mathrm{NO}_{\mathrm{X}}$ reduction from LNT to SCR, fuel consumption penalty due to LNT enrichment can be reduced. Finally, the combination system was demonstrated in transient test cycles and by real driving operation on road.
\end{abstract}

T. Wittka $\cdot$ P. Dittmann $(\bowtie) \cdot$ S. Pischinger

Institute for Combustion Engines, RWTH Aachen University,

Aachen, Germany

e-mail: dittmann@vka.rwth-aachen.de

B. Holderbaum

FEV GmbH, Aachen, Germany
Keywords $\mathrm{NO}_{\mathrm{X}} \cdot \mathrm{LNT} \cdot \mathrm{SCR} \cdot \mathrm{LNT}+\mathrm{SCR} \cdot \mathrm{NH}_{3}$ formation $\cdot$ Diesel reformer

\section{Introduction}

Worldwide, more stringent pollutant and $\mathrm{CO}_{2}$ emission limitation in upcoming legislation norms for diesel passenger car applications require the introduction of exhaust aftertreatment systems with increased purification and energetic efficiency. In addition to more restrictive emission limits, new European emission evaluation test procedures, like Worldwide harmonized Light vehicles Test Procedure (WLTP), real driving emissions (RDE), and Portable Emissions Measurement System (PEMS) result in an enlarged emission relevant engine operation area. Beside the increased coverage of engine load and speed, also the emission testing including cold start and high temperature cycles demands an extended active temperature range of aftertreatment systems. Both state-of-the-art technologies for mobile $\mathrm{NO}_{\mathrm{X}}$ reduction, lean $\mathrm{NO}_{\mathrm{X}}$ trap (LNT), and selective catalytic reduction catalyst (SCR) show challenges for robust performance under strongly extended emission relevant operation conditions. One technical solution on the aftertreatment side is the combination of LNT and SCR functionalities. To avoid urea necessity in active SCR systems, the combination of LNT and passive SCR (without urea dosing) was favored in this study over the two alternative combination systems based on active SCR (LNT + active SCR; passive $\mathrm{NO}_{\mathrm{X}}$ adsorber (PNA)+active $\mathrm{SCR}$ ).

The LNT + passive SCR combination were the center of research of several previous studies. A schematic overview of general layout concepts is shown in Fig. 1. Moreover, general positions of the fuel reformer functionality are integrated. In principle, the combination can be realized by a parallel or 


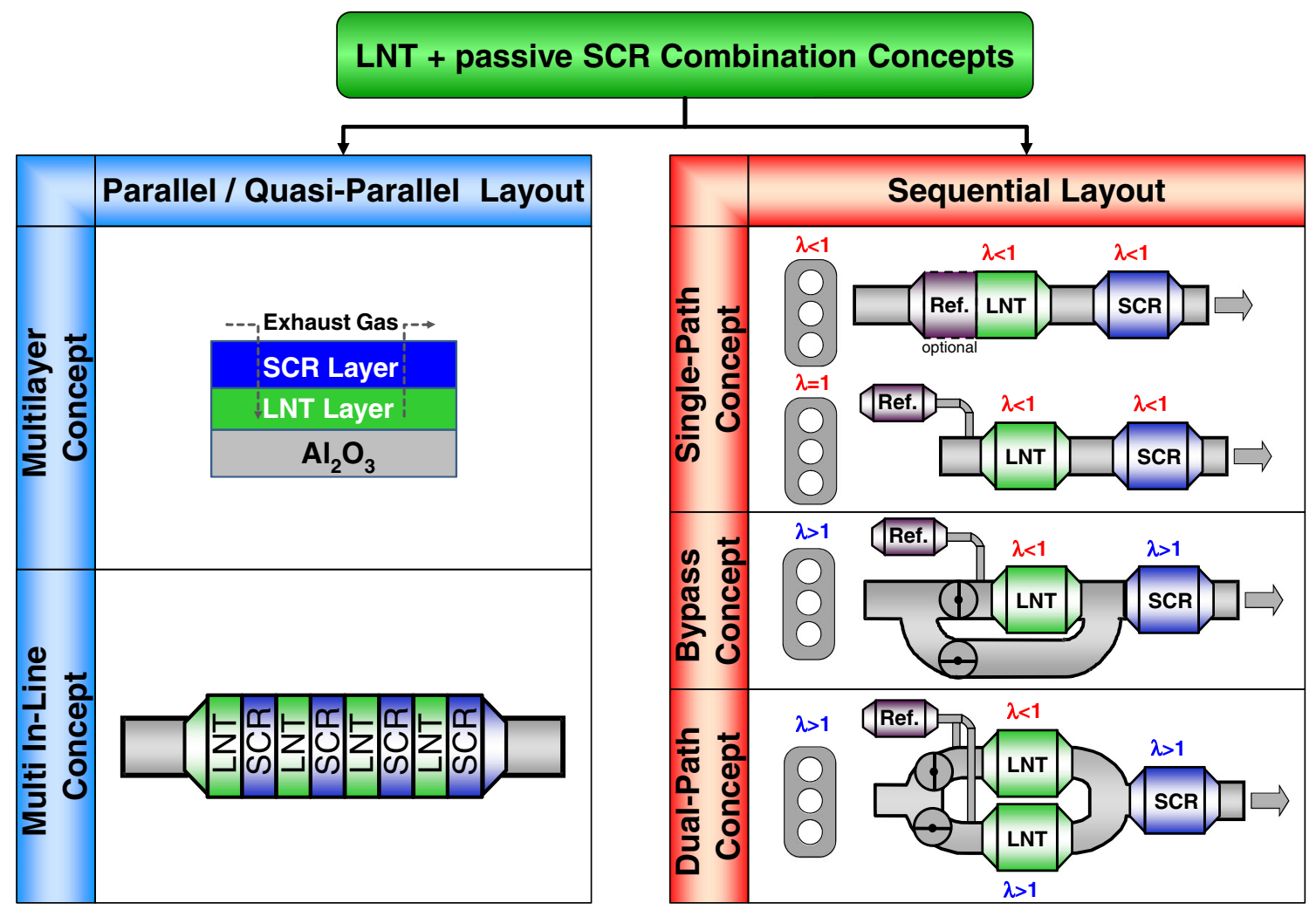

Fig. 1 Schematic overview of general layout concepts for LNT and passive SCR combination systems

quasi-parallel layout or by a sequential layout. The intention of a parallel layout in a multilayer design [1-5] or of a quasiparallel layout in a multi in-line design [6] is the in situ utilization by storage and conversion of the axial $\mathrm{NH}_{3}$ formation during the LNT regeneration. In this layout, the intermediate $\mathrm{NH}_{3}$ does not get re-oxidized but stored on the SCR layer or slice. Thereby, high $\mathrm{NH}_{3}$ amounts might be used for $\mathrm{NO}_{\mathrm{X}}$ conversion on the SCR. Nevertheless, the impact of the acid SCR on the alkaline LNT surface and its storage performance of acid $\mathrm{NO}_{\mathrm{X}}$ as well as the SCR poisoning by hydrocarbons (HC) and the absence of $\mathrm{O}_{2}$ during the rich operation is still open. Additionally, flexibility in shifting of $\mathrm{NO}_{\mathrm{X}}$ conversion between LNT and SCR by application is not possible. During the $\mathrm{LNT} \mathrm{NO}_{\mathrm{X}}$ adsorption period, as the $\mathrm{LNT} \mathrm{NO}_{\mathrm{X}}$ load axially increases, the $\mathrm{SCR} \mathrm{NH} \mathrm{NH}_{3}$ load gets axially consumed.

In the sequential layout, the passive SCR is only operated by the $\mathrm{NH}_{3}$, which is emitted from the LNT at the end of the LNT regeneration. The design can be set up as a single-path [7-20] bypass [21-23] or dual-path [24, 25] concept. The single-path concept requests in any case a specific engine operating mode for the LNT regeneration. Comparable to conventional LNT application, the LNT regeneration can be conducted by engine internal enrichment. Optionally, an in-line reformer catalyst might be installed upstream of the LNT for increasing $\mathrm{H}_{2}$ and $\mathrm{CO}$ and decreasing $\mathrm{HC}$ concentrations and thereby improving especially the regeneration efficiency at low temperature. However, due to the necessity of high reformer operation temperatures usually in the range of 800$950{ }^{\circ} \mathrm{C}$ for sufficient reforming activity, the capability of an inline reformer is limited. In case of reductant breakthrough, the SCR is operated at an air-to-fuel ratio $\mathrm{A} / \mathrm{F}(\lambda)$ below 1 with the risk of $\mathrm{HC}$ poisoning. Alternatively, an out-line reformer might be controlled in optimum operation range, resulting in enhanced reformate composition regarding $\mathrm{H}_{2}$ and $\mathrm{CO}$ concentration. Nevertheless, the engine still has to be operated at least at $\lambda=1$ to minimize excess residual $\mathrm{O}_{2}$ in the exhaust gas and high exothermic reactions on the LNT during the regeneration. In contrast to the single-path concept, both bypass and dual-path concepts do not require any engine internal operation mode change. However, in any case, these concepts need an out-line fuel reformer. The engine can be operated independently at $\lambda>1$ due to local enrichment of solely the LNT. In the dual-path concept, the two LNTs are operated alternatively by switching the exhaust gas flaps. The LNT bypass in the bypass concept is only activated during the LNT regeneration.

The intrinsic ammonia $\left(\mathrm{NH}_{3}\right)$ formation on the LNT during the rich LNT regeneration is one key functionality for combined concepts with passive SCR. A number of recent studies focused on the mechanism and the influence of regeneration conditions and catalyst formulation. The discontinuous understoichiometric $(\lambda<1$, also called "rich") reduction of the adsorbed $\mathrm{NO}_{\mathrm{X}}$ on the LNT during the LNT regeneration by excessive feeding of unburned $\mathrm{HC}$, carbon monoxide (CO), and hydrogen $\left(\mathrm{H}_{2}\right)$ is typically realized by engine internal rich 
operation $\left(\lambda_{\text {exhaust }}=\lambda_{\text {engine }}<1\right)$. Alternatively, the reductant species can be dosed engine externally by fuel or reformate gas injection directly into the exhaust gas upstream of the LNT $\left(\lambda_{\text {exhaust }}<1, \lambda_{\text {engine }} \geq 1\right)$. Under this reducing exhaust gas conditions, various elementary reactions take place on the LNT surface. However, the surface reaction system is not fully selective toward the desired product nitrogen $\left(\mathrm{N}_{2}\right)$ but also results in products $\mathrm{NH}_{3}$ and nitrous oxide $\left(\mathrm{N}_{2} \mathrm{O}\right)$. Figure 2 gives a simplified and schematic overview of the main elementary surface $\mathrm{N}$-species during the under-stoichiometric LNT regeneration and possible gaseous products. Starting point are the adsorption of $\mathrm{NO}$ and $\mathrm{NO}_{2}$ and subsequent dissociation steps. The $\mathrm{NH}_{3}$ formation is mainly described by multiple elementary reactions with $\mathrm{H}(\mathrm{s})$ to $\mathrm{NH}_{3}(\mathrm{~s})$ and final desorption [26-29]. Alternatively (not displayed in Fig. 2), reaction pathways over isocyanate species $\mathrm{NCO}(\mathrm{s})$ and subsequent hydrolysis to $\mathrm{NH}_{3}$ are in discussion [28, 30-32].

In principle, a distinction has to be made between the discontinuous $\mathrm{NH}_{3}$ formation inside the reaction front from previously stored $\mathrm{NO}_{\mathrm{X}}$ and the continuous $\mathrm{NH}_{3}$ formation behind the reaction front from gaseous $\mathrm{NO}_{\mathrm{X}}$ feed into the catalyst. According to the state of knowledge, inside the reaction front, which axially propagates through the LNT during the rich regeneration [33-36], $\mathrm{NH}_{3}$ is intermediately [37-39] formed by over-reduction of $\mathrm{NO}_{\mathrm{X}}$. The so-formed $\mathrm{NH}_{3}$ behaves as reductant like $\mathrm{HC}, \mathrm{CO}$, and $\mathrm{H}_{2}$. It re-oxidizes, e.g., to nitrogen [40] by reaction with surface oxygen sources (oxygen storage capacity (OSC), nitrate $\left(\mathrm{NO}_{\mathrm{X}}\right)$ ) downstream the reaction front. At the end of the LNT regeneration, when the rich reaction front reaches the catalyst outlet, the intermediate $\mathrm{NH}_{3}$ cannot be reoxidized anymore and typically gets emitted as $\mathrm{NH}_{3}$ peak. These principle $\mathrm{NH}_{3}$ formation processes are strongly influenced by the catalyst formulation $[7,8,41-50]$ (load, type, and dispersion of platinum group metals (PGMs), $\mathrm{NO}_{\mathrm{X}}$ adsorbent type, OSC load, aging influence), reaction conditions [33-35, 37, 44, 51-55] (temperature, reductant species), and LNT regeneration strategy $[26,27,51,56,57]\left(\mathrm{LNT} \mathrm{NO}_{\mathrm{X}}\right.$ load, regeneration duration, concentration of reductant species).

The main targets of the investigation results discussed in this study are the demonstration of the combination of LNT and passive SCR as well as a detailed insight into the influence of the LNT regeneration strategy on the $\mathrm{NH}_{3}$ formation. Therefore, commercial and full size catalyst formulations with onboard generated $\mathrm{H}_{2}$ and $\mathrm{CO}$ reductant species were investigated under realistic boundary conditions on test bench and in a demonstrator vehicle.

\section{Description of Aftertreatment Concept}

The investigated LNT-based aftertreatment system comprises an LNT plus exhaust bypass, a downstream positioned passive SCR (without active urea dosing), and an onboard exhaust gas fuel reformer. In contrast to the current technical trend of positioning the $\mathrm{NO}_{\mathrm{X}}$ purification systems (LNT, SCR-coated diesel particulate filter (DPF)) as close as possible to engine out due to cold start reasons, the investigated $\mathrm{DeNO}_{\mathrm{X}}$ system (LNT+passive SCR) is placed underfloor. So, it is downstream of the serial close-coupled diesel oxidation catalyst (DOC) + cDPF unit and low-pressure exhaust gas recirculation (EGR) branch (LP-EGR). Beside cold start operation, the study focuses as well on RDE with high-temperature operation. Under these conditions, a close-coupled LNT position might be disadvantageous due to limited high-temperature $\mathrm{NO}_{\mathrm{X}}$ adsorption capacity as well as limited $\mathrm{NH}_{3}$ formation tendency. Additionally, the position upstream of the LPEGR branch could be unfavorable. The increased exhaust and hence $\mathrm{NO}_{\mathrm{X}}$ mass flow would result in fast consumption of the LNT $\mathrm{NO}_{\mathrm{X}}$ storage capacity as well as $\mathrm{SCR} \mathrm{NH}_{3}$ load. The final concept layout and the simplified method of operation are shown schematically in Fig. 3.

The system is discontinuously operated in two operation modes. During $\mathrm{NO}_{\mathrm{X}}$ adsorption mode, the total system is operated under lean condition. The LNT exhaust path is opened; the LNT bypass is closed. $\mathrm{NO}_{\mathrm{X}}$ treatment takes place either by $\mathrm{NO}_{\mathrm{X}}$ adsorption on the LNT or continuous reduction on the SCR by consuming previously stored $\mathrm{NH}_{3}$. The integrated onboard exhaust gas fuel reformer is inactive. Opening the bypass path and closing the LNT path leads to a feed of $\mathrm{H}_{2}$ and $\mathrm{CO}$ containing reformate gas at low space velocity via the activated fuel reformer. Consequently, the LNT is locally enriched for the frequently necessary LNT regeneration. The
Fig. 2 Simplified and schematic overview of the main elementary surface $\mathrm{N}$-species during the under-stoichiometric LNT regeneration (educt adsorption, product desorption, elementary surface reactions for $\mathrm{O}(\mathrm{s})$ consumption, and back reactions are not displayed; $(s)$ symbolizes adsorbed species)

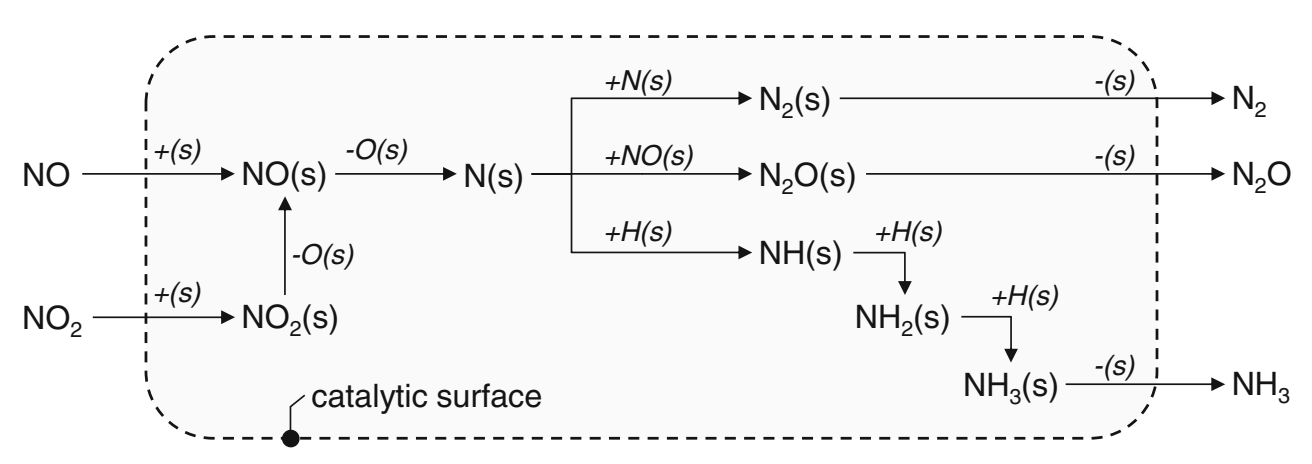


Fig. 3 Simplified operation method of combined aftertreatment system with closecoupled DOC + cDPF, underfloor LNT plus exhaust bypass, passive SCR, and integrated exhaust gas fuel reformer

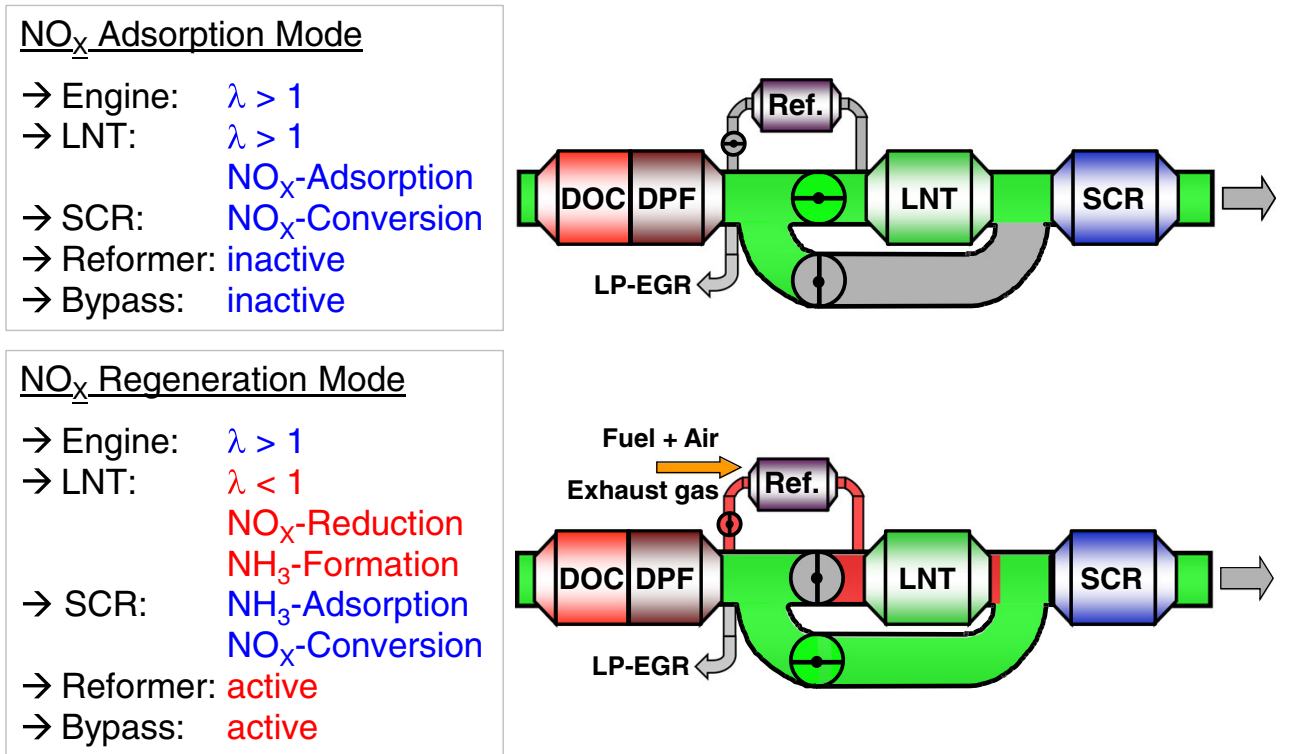

temperature of the reformate gas is below $200{ }^{\circ} \mathrm{C}$ due to not insulated reformate pipes. By pipe insulation, the residual reformate heat could be used for LNT heating. The exhaust paths are actuated by two exhaust flaps, well known from serial application. The exhaust mass flow slip over the closed flap is below $5 \%$. The LNT regeneration is controlled in terms of high $\mathrm{NH}_{3}$ formation and emission. The $\mathrm{NH}_{3}$ emitted during the LNT regeneration adsorbs on the SCR and increases the $\mathrm{SCR} \mathrm{NH}_{3}$ load for the next $\mathrm{NO}_{\mathrm{X}}$ adsorption mode. After the end of the $\mathrm{NO}_{\mathrm{X}}$ regeneration mode, the exhaust flaps are switched back into $\mathrm{NO}_{\mathrm{X}}$ adsorption mode for the next adsorption-regeneration cycle. The integrated onboard fuel reformer is predominantly operated by exhaust gas, which is taken downstream of the DPF. Diesel is injected by an airassisted, low-pressure injector at a significant understoichiometric air/fuel ratio $\left(\lambda_{\text {Ref }}=0.35-0.80\right)$ and is catalyzed to a $\mathrm{H}_{2}$ - and $\mathrm{CO}$-rich synthesis gas. The reaction enthalpy, which is released a ring-shaped reformer catalyst, supports fuel vaporization via internal heat transfer. The reforming reaction process can be described by superposition of exothermic partial oxidation (POx) by the residual oxygen in the exhaust gas as well as the secondary air and endothermic steam (SR) and $\mathrm{CO}_{2}$ reforming (DR) which occurs via the $\mathrm{H}_{2} \mathrm{O}$ and $\mathrm{CO}_{2}$ introduced by the exhaust gas. Furthermore, the reforming products are temperature-dependent in chemical equilibrium, among others mainly according to the water-gas shift (WGS) and methanation reaction. In comparison to pure POx, exhaust gas reforming offers favorable thermal behavior as well as benefits regarding $\mathrm{H}_{2}$ and $\mathrm{CO}$ yield, due to the endothermic reforming reactions. The reformer operation is strongly dependent on the exhaust gas composition. The reformer itself is controlled in terms of maximizing $\mathrm{H}_{2}$ and $\mathrm{CO}$ as well as minimizing $\mathrm{HC}$ concentration in the reformate, while complying with temperature limits.

\section{Experimental}

\subsection{Catalyst Preparation}

The LNT and SCR catalysts for full-scale investigation were prepared based on metallic substrates with platinum $(\mathrm{Pt})$ and rhodium $(\mathrm{Rh})$ as catalytically active components. Two different LNT formulations (called "LNT A" and "LNT B") were tested, which basically consisted of different sets of $\mathrm{NO}_{\mathrm{X}}$ adsorbents. Additionally, the PGM load of the LNT was varied ("PGM low": $85 \mathrm{~g} / \mathrm{ft}^{3}$ and "PGM high": $130 \mathrm{~g} / \mathrm{ft}^{3}$ ). The SCR catalyst is copper $(\mathrm{Cu})$ zeolite based and close to conventional commercial formulation. In all investigations shown here, the volume of the LNT is $1.4 \mathrm{~L}$ and of the SCR $2.9 \mathrm{~L}$. Only in the vehicle experiments, a DOC-like slip catalyst of $0.8 \mathrm{~L}$ was installed directly downstream of the SCR mainly for oxidizing CO slip from the LNT regeneration. The catalysts were not full lifetime aged but thermally conditioned by several hours of DPF regeneration operation in real exhaust gas (hydrothermally aged). The reformer catalyst is ring-shaped and based on ceramic substrate with a PGM load of $60 \mathrm{~g} / \mathrm{ft}^{3}$ and a volume of $0.5 \mathrm{~L}$. The exhaust bypass is operated by serial exhaust flaps (application in LP-EGR systems). Diesel is injected into the reformer mixing chamber by a serial air-assisted, lowpressure $(<5$ bar) injector.

\subsection{Engine Test Bench Experiments}

The full-scale experiments for investigating the $\mathrm{NO}_{\mathrm{X}}$ purification behavior of the combination system as well as the performance of the fuel reformer were conducted with a high efficient $1.4 \mathrm{~L}$ three-cylinder diesel engine on a transient engine test bench. The new developed control logic of the aftertreatment system was running on a rapid control system 
(ES1000 Fa. ETAS) independently from the engine. The necessary information was transferred between engine and aftertreatment control via ECU bypass. In steady-state investigations, the engine operation (speed, load, operation mode) was set in order to adjust target conditions at the LNT (temperature, $\mathrm{NO}_{\mathrm{X}}$ concentration, exhaust mass flow, $\mathrm{A} / \mathrm{F}$ ratio). Additionally, transient test cycles (New European Driving Cycle (NEDC), Worldwide harmonized Light duty driving Test Cycle (WLTC), FTP75, CADC, US06, ADAC) were conducted in order to evaluate and calibrate the system performance and operation strategy. The emissions were measured by different analyzers (CLD: $\mathrm{NO}_{\mathrm{X}}$, NO; NDIR: $\mathrm{CO}, \mathrm{CO}_{2}$; Magnos: $\mathrm{O}_{2}$; FID: THC; FTIR: $\mathrm{NO}, \mathrm{NO}_{2}, \mathrm{CO}, \mathrm{CO}_{2}, \mathrm{H}_{2} \mathrm{O}, \mathrm{NH}_{3}, \mathrm{~N}_{2} \mathrm{O}$, $\mathrm{CH}_{4}, \mathrm{SO}_{2}$; LDS: in situ $\mathrm{NH}_{3}$; mass spectrometer: $\mathrm{H}_{2}, \mathrm{H}_{2} \mathrm{~S}$, $\left.\mathrm{SO}_{2}, \mathrm{COS}, \mathrm{CS}_{2}\right)$ and sensors $\left(\mathrm{NO}_{\mathrm{X}}, \lambda\right)$ at various positions (engine out, downstream of the DPF, upstream and downstream of the SCR). The process mass spectrometer (PrMS) is an analytical unit constructed by V\&F including the TWINMS (CIMS with soft ionization by source gases: $\mathrm{Xe}, \mathrm{Kr}, \mathrm{Hg}$ ) and the H-Sense (EI with ionization by ion beam), which allows to detect all data parallel in lifetime with a very high dynamic (30 ms for each substance). The gas composition of the out-line exhaust gas fuel reformer was calculated based on emission measurements in the full exhaust gas flow and the according dilution factor. The total aftertreatment system was set up very modularly by the possibility of replacing each catalyst unit by an empty exhaust pipe. Additionally to the onboard fuel reforming, fundamental investigations of the LNT regeneration were performed by bottled synthetic reformate gas, which was dosed by a mass flow controller (MFC). Based on the achieved onboard reformate gas composition, the bottled reformate substitute gas contains molar fractions of $20 \% \mathrm{H}_{2}, 20 \% \mathrm{CO}$, and $60 \% \mathrm{~N}_{2}$. A schematic overview of the experimental setup on the engine test bench is given in Fig. 4.

\subsection{Vehicle Experiments}

The exhaust aftertreatment system was investigated in a Volkswagen Golf Variant, basically with the same engine specification and aftertreatment layout as on the engine test bench (Fig. 5). In contrast to the engine test bench investigations, a DOC-like slip catalyst was positioned downstream of the SCR mainly for oxidizing CO slip from the LNT

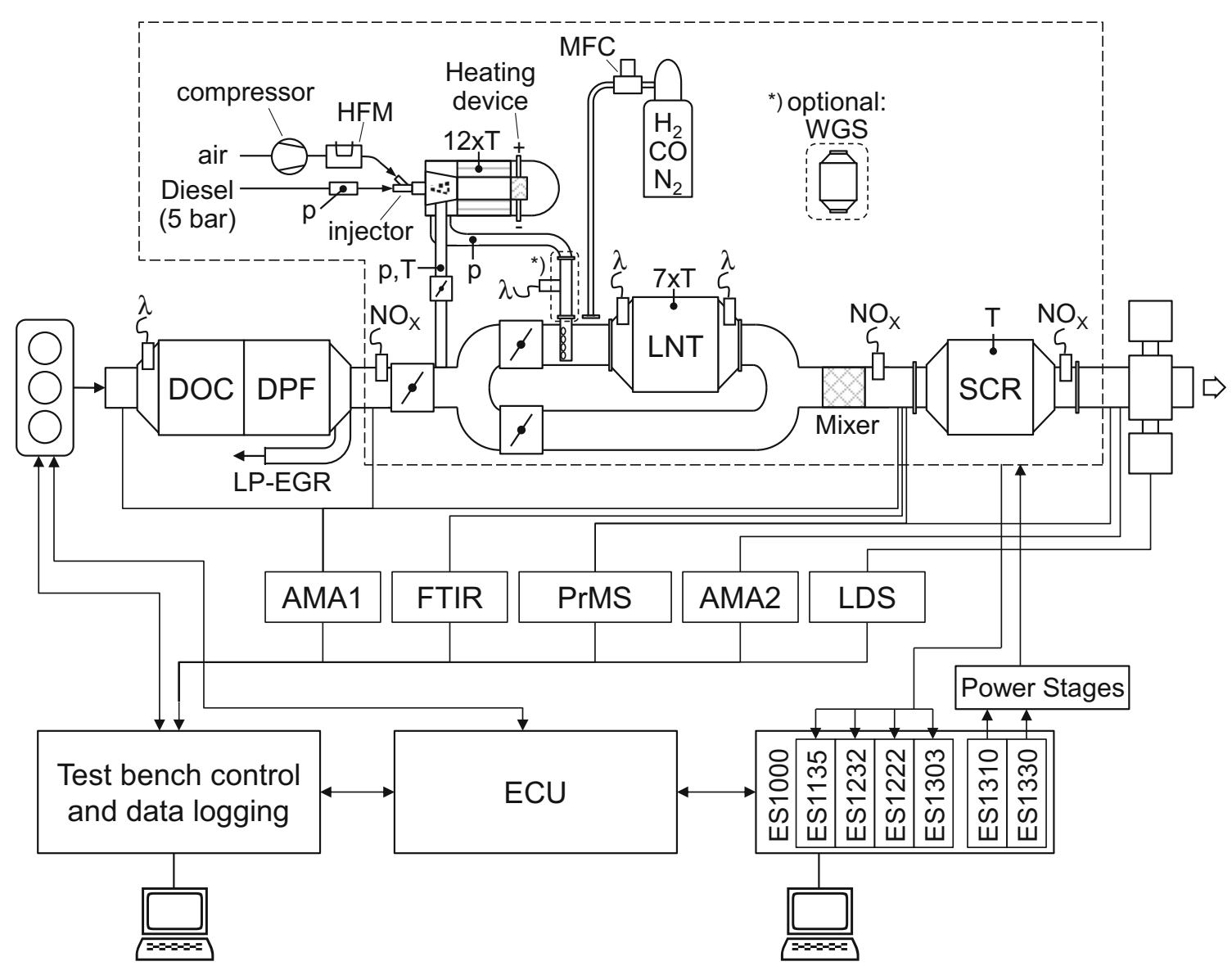

Fig. 4 Schematic experimental setup on engine test bench: overview of exhaust gas analyzers, sensors, actuators, and rapid prototyping control (AMA: exhaust analyzer system comprising chemiluminescence detection, non-dispersive infrared spectrometry, flame ionization detection and $\mathrm{O}_{2}$ detection) 
Fig. 5 Final integration of the combined aftertreatment system into the demonstrator vehicle (viewing direction underfloor, left: front, right: rear)

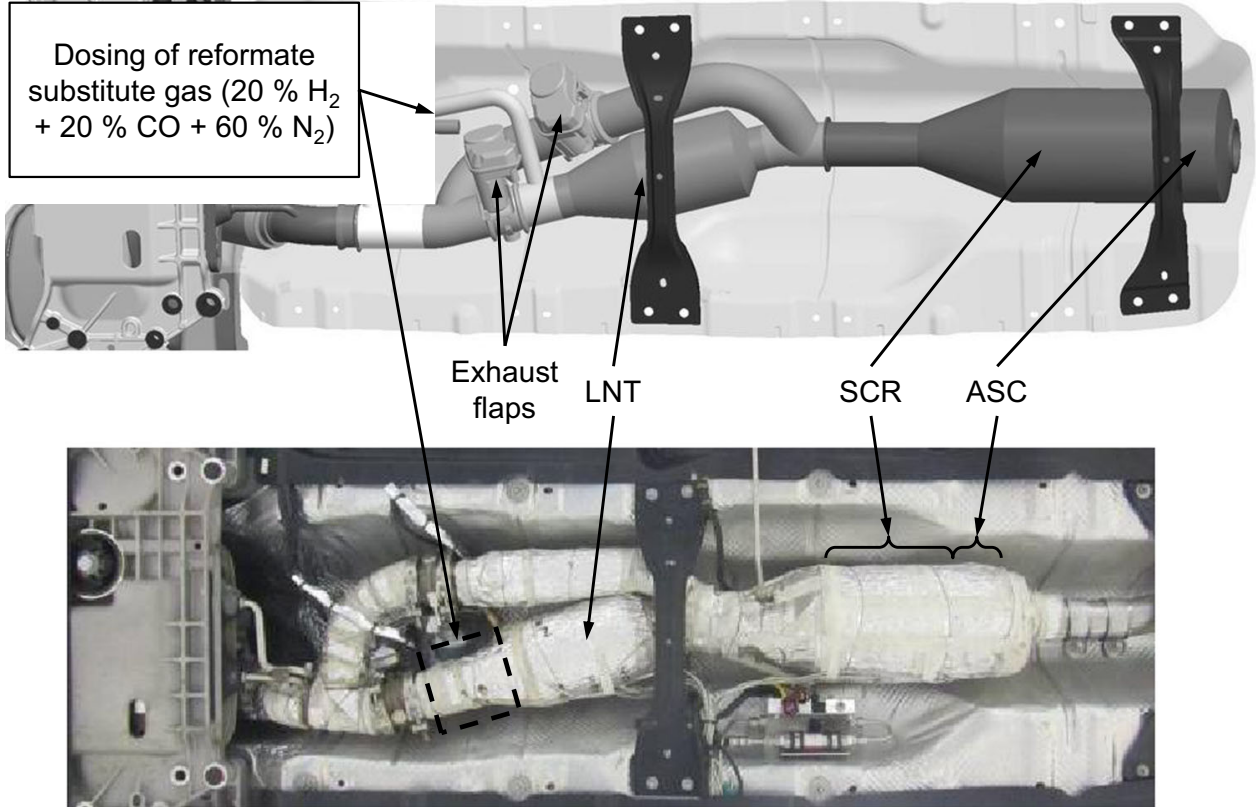

regeneration. The LNT regeneration was performed by bottled reformate substitute gas, of the same composition as on the engine test bench. The system was investigated by transient testing in NEDC and WLTC on a chassis roller test bench with an inertia mass of $1590 \mathrm{~kg}$ and on road in real driving (RDE) with "soft", "normal", and "aggressive" driving style. Due to the additional control equipment and passengers, the real vehicle mass on road was $1780 \mathrm{~kg}$ without PEMS and $1970 \mathrm{~kg}$ with PEMS. The RDE cycle had a distance of approx. $90 \mathrm{~km}$ with a share of approx. 1/3 urban driving, 1/3 rural driving, and $1 / 3$ highway driving.

\section{Results and Discussion}

\subsection{Exhaust Fuel Reformer}

The fuel reformer was intensively studied but is not part of this paper. However, for better understanding and ranking of the fuel economy penalty caused by LNT regeneration, which is discussed later, the reductant formation yield $\left(Y_{\text {Red }}\right)$ is an important indicator in terms of energetic efficiency. $Y_{\text {Red }}$ is defined as ratio of oxygen consumption potential of the reducing agent available in the exhaust gas relative to the additional fuel introduced to reach rich operation. It can generally be calculated by Eq. 1 or for engine operation in case of non-available measurement of all exhaust gas species also by Eq. 2 . The theoretical optimum reductant yield is represented by the direct use of fuel for the LNT regeneration, e.g., by fuel injection upstream of the LNT with closed exhaust flap. In this case, the reductant yield is $100 \%$.
However, injecting liquid or even pre-vaporized fuel into almost zero exhaust mass flow is hardly practicable.

$Y_{\mathrm{Red}}=\frac{\dot{n}_{\mathrm{H}_{2}}+\dot{n}_{c o}+\left(2 x+\frac{y}{2}\right) \cdot n_{C_{x}}-2 \cdot n_{O_{2}}-n_{N O}-2 \cdot n_{N O_{2}}}{\left(2 x+\frac{y}{2}\right) \cdot n_{C_{x} H_{y}, \text { Diesel }}}$

$Y_{\text {Red,engine }}=\frac{\dot{m}_{\text {engine fuel, }, \text { rich mode }} \cdot\left(1-\lambda_{\text {engine, } r i c h \text { mode }}\right)}{\dot{m}_{\text {engine fuel, }, \text { rich } \text { mode }}-m_{\text {engine fuel, lean } \text { mode }}}$

The conventional LNT regeneration done by engine internal enrichment is mainly achieved by throttling and hence intake oxygen reduction as well as applying early and late post injections for excess $\mathrm{HC}, \mathrm{CO}$, and $\mathrm{H}_{2}$ concentrations. However, the main portion of the additionally injected fuel is consumed for compensating combustion efficiency losses caused by engine measures to reduce the typical lean diesel air-to-fuel ratio toward $\lambda=1$. As shown in Fig. 6 , only $10-45 \%$ of the additionally expended fuel is available as reducing agent in the exhaust gas. The scatter band in Fig. 6 includes various current diesel engine calibrations. The reductant yield is slightly increasing with increasing BMEP or decreasing A/F ratio during normal lean operation mode. Besides drivability and acoustic reasons, engine internal enrichment should be conducted during vehicle acceleration for lowering the fuel economy penalty (FEP) for LNT regeneration. However, the maximum achievable reductant yield is limited by frequency and length of high engine load periods. In contrast to the diesel engine enrichment, the reductant yield of the fuel reformer reaches a significantly higher level of about $50-60 \%$, as 


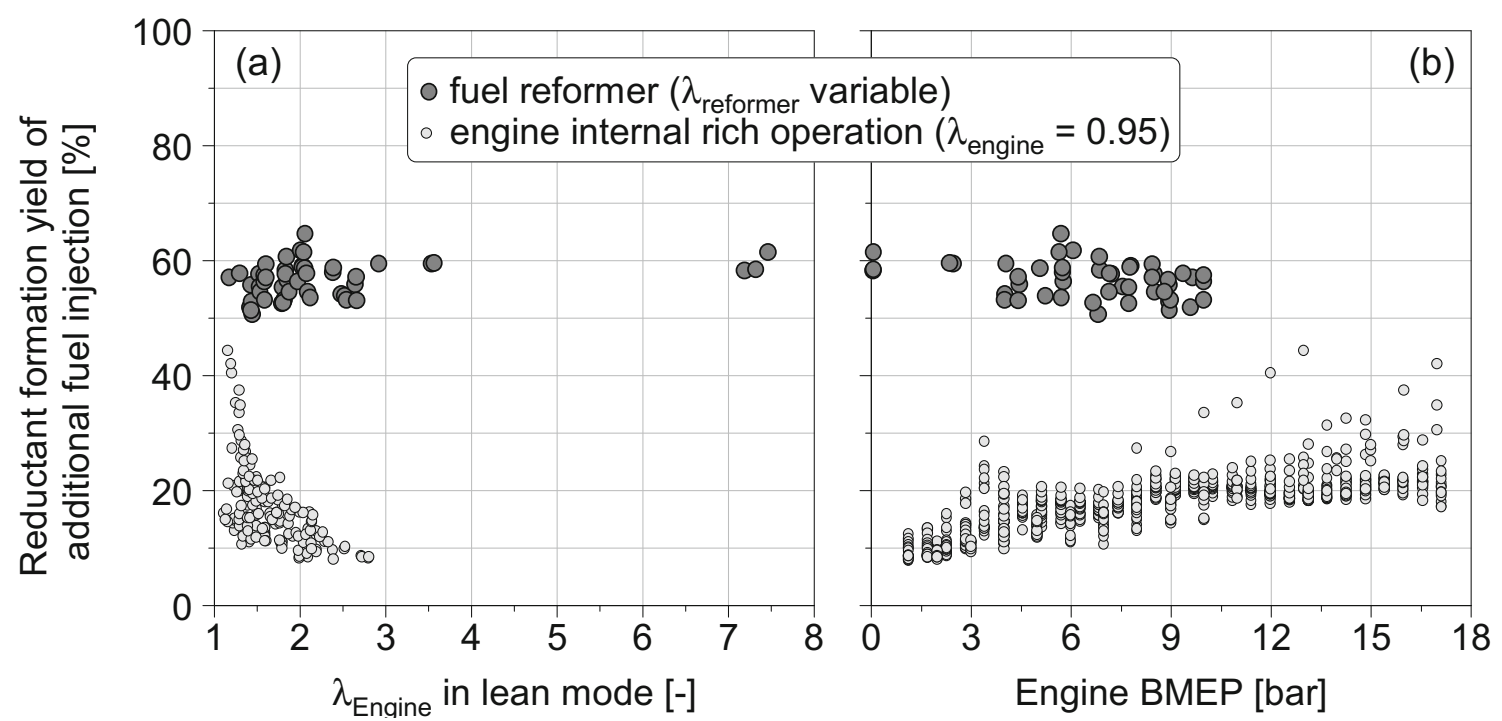

Fig. 6 Reductant formation yield of additional fuel for LNT enrichment by fuel reforming in comparison to diesel engine enrichment of various engine calibrations $\mathbf{a}$ as function of A/F ratio of the engine during lean operation and $\mathbf{b}$ as function of the engine's brake mean effective pressure (BMEP)

shown in Fig. 6. The $\mathrm{A} / \mathrm{F}$ ratio and temperature of the exhaust gas fuel reformer were optimized by the reformer control algorithm for each single operation point with regard to low $\mathrm{HC}$ emission and high energetic efficiency. The reformer $\mathrm{A} / \mathrm{F}$ ratio is in the range of 0.35 to 0.80 . The reformer temperature reaches 750 and $950{ }^{\circ} \mathrm{C}$. The reductant loss in the reformer is caused by the partial oxidation of the fuel with oxygen from lean exhaust gas or secondary air. Nevertheless, the reformer enables to decrease the fuel economy penalty and $\mathrm{CO}_{2}$ emissions for the LNT regeneration in comparison to the conventional approach by engine internal rich operation. (a) LNT NO load: $1.0 \mathrm{~g}$
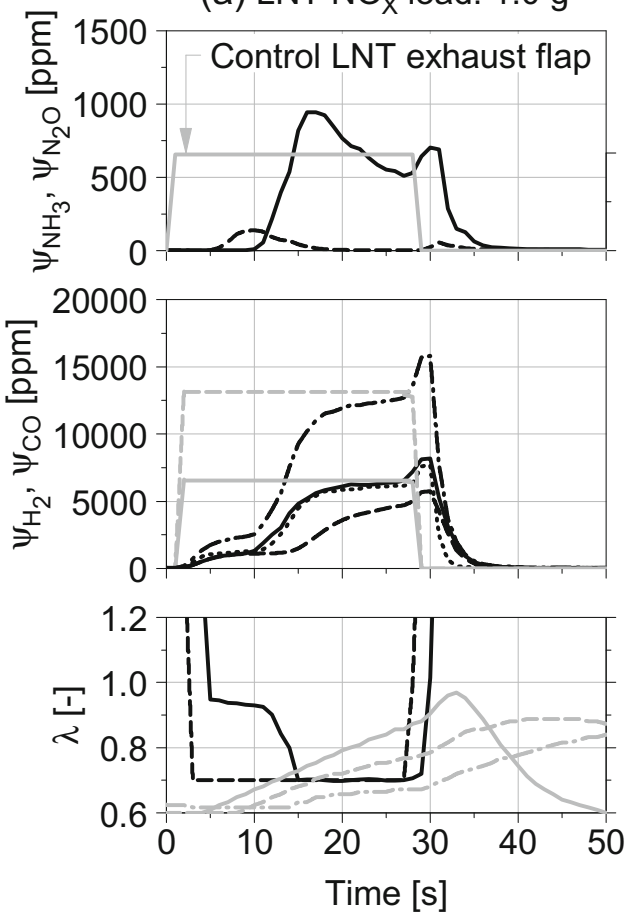

Fig. 7 LNT regeneration as function of time at $250^{\circ} \mathrm{C}$ : concentrations of the reductants $\mathrm{H}_{2}$ and $\mathrm{CO}$ as well as of the secondary emissions $\mathrm{NH}_{3}$ und $\mathrm{N}_{2} \mathrm{O}$ downstream of the LNT in the full exhaust gas, $\mathrm{A} / \mathrm{F}$ ratio upstream and downstream of the LNT, temperatures inside LNT, a $1.0 \mathrm{~g} \mathrm{NO}_{\mathrm{X}}$ load, (b) LNT NO load: $2.5 \mathrm{~g}$
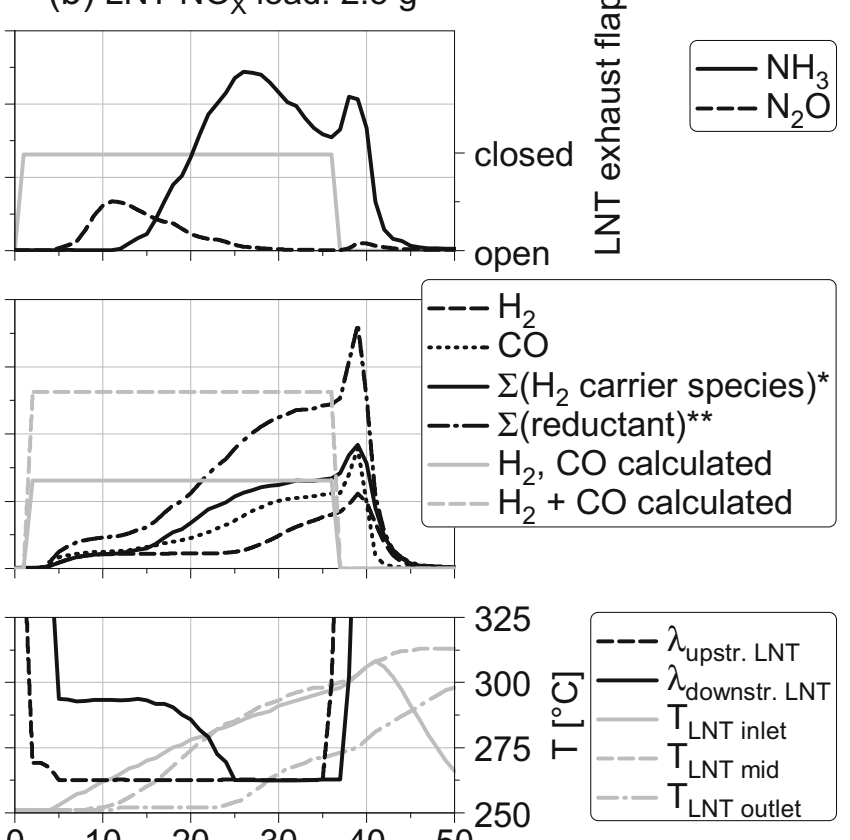

Time $[\mathrm{s}]$

b $2.5 \mathrm{~g} \mathrm{NO}_{\mathrm{X}}$ load (reformate substitute dosing $=45 \mathrm{~g} / \mathrm{min}, \mathrm{SV}_{\mathrm{LNT}, \mathrm{Reg}}=$ $3900 \mathrm{~h}^{-1}$, LNT A "PGM high"), $* \Sigma\left(\mathrm{H}_{2}\right.$ carrier species $)=\psi_{\mathrm{H} 2}+3,5$ $\psi_{\mathrm{NH} 3}+3 \psi_{\mathrm{CH} 4}, * * \Sigma$ (reductants) $=\psi_{\mathrm{H} 2}+3,5 \psi_{\mathrm{NH} 3}+4 \psi_{\mathrm{CH} 4}+\psi_{\mathrm{CO}}$ 


\section{2 $\mathrm{LNT} \mathrm{NH}_{3}$ Formation}

The LNT regeneration strategy has a high impact on $\mathrm{NH}_{3}$ formation and emission. Due to the key function of the $\mathrm{NH}_{3}$ formation for a passive SCR system, the influence of the LNT temperature, of the LNT $\mathrm{NO}_{\mathrm{X}}$ load, and of the regeneration duration on the $\mathrm{NH}_{3}$ emission are discussed in detail.

Two LNT regenerations showing gas concentrations, $\mathrm{A} / \mathrm{F}$ ratios, and temperatures as function of time at $250{ }^{\circ} \mathrm{C}$ for 1.0 and $2.5 \mathrm{~g} \mathrm{NO}_{\mathrm{X}}$ load are reported in Fig. 7. Basically, the regeneration period can be divided into two phases. In phase 1 , the LNT reduction takes place (typical $\lambda_{\text {downstream LNT }}=1$ ). The completion of enrichment is identifiable by $\lambda$ breakthrough $\left(\lambda_{\text {downstream LNT }}<0.95\right)$. Phase 2 defines the regeneration duration after $\lambda$-breakthrough. In line with current literature, the $\mathrm{NH}_{3}$ emission starts at the end of phase 1 . The LNT enrichment in conventional application is stopped at the end of phase 1 in order to avoid reductant and $\mathrm{NH}_{3}$ slip. However, the lean exhaust gas downstream of the SCR caused by the bypass system offers reductant slip oxidation and therefore significantly elongated rich duration, which enables enlarged $\mathrm{NH}_{3}$ emission. The long $\mathrm{NH}_{3}$ emission profile indicates that the $\mathrm{NO}_{\mathrm{X}}$ load is still not completely reduced even in the case of $\lambda$-breakthrough and high reductant slip. In the given example at $250{ }^{\circ} \mathrm{C}$ and $1.0 \mathrm{~g} \mathrm{NO}_{\mathrm{X}}$ load, the profile of the sum of all $\mathrm{H}_{2}$ carrier reductant species $\left(\mathrm{H}_{2}, \mathrm{NH}_{3}, \mathrm{CH}_{4}\right)$ equals the $\mathrm{CO}$ profile downstream of the LNT. This suggests that $\mathrm{NH}_{3}$ is only formed by the $\mathrm{H}_{2}$ feed at this temperature $\left(\mathrm{CH}_{4}\right.$ not evident). At higher temperatures (not shown), the profile comparison suggests that also $\mathrm{CO}$ contributes to the $\mathrm{NH}_{3}$ formation. However, it is not possible to distinguish between a direct $\mathrm{CO}$ path and $\mathrm{CO}$ consumption by WGS and subsequent $\mathrm{NH}_{3}$ formation by the newly formed $\mathrm{H}_{2}$. The final $\mathrm{NH}_{3}$ emission peak during opening the LNT exhaust flap is caused by sudden purging and hence less dilution of the formed $\mathrm{NH}_{3}$ in the full exhaust gas upstream of the SCR. $\mathrm{N}_{2} \mathrm{O}$ emission is evident mostly during the beginning of the LNT reduction in phase 1 as well as after the regeneration during the switch back from rich to lean conditions. Possibly, the adsorbed $\mathrm{N}$-species get oxidized during the $\mathrm{O}_{2}$-flush.

The $\mathrm{NH}_{3}$ formation yield (molar ratio of cumulated $\mathrm{NH}_{3}$ amount during LNT regeneration to initial LNT $\mathrm{NO}_{\mathrm{X}}$ load at LNT regeneration start, Eq. 3) or the $\mathrm{NH}_{3}$ formation selectivity (molar ratio of cumulated $\mathrm{NH}_{3}$ amount during LNT regeneration to converted $\mathrm{NO}_{\mathrm{X}}$, Eq. 4) are important parameters for operating the combined system. Figure 8 shows the $\mathrm{NH}_{3}$ selectivity as function of LNT temperature for various regeneration durations after $\lambda$-breakthrough in comparison for LNT A (low and high PGM) and LNT B.

$Y_{N H_{3}}=\frac{n_{N H_{3}}}{n_{N O_{X} \text { loadLNT }}}$

$S_{N H_{3}}=\frac{n_{N H_{3}}}{n_{N O_{X} \text { converted }}}$

Independent of the LNT type, the $\mathrm{NH}_{3}$ selectivity strongly increases with prolonged LNT enrichment after $\lambda$ breakthrough and saturates at higher durations. Nevertheless, it must be mentioned that the $\mathrm{NH}_{3}$ emission occurs roughly in parallel to reductant breakthrough. Therefore, high $\mathrm{NH}_{3}$ formation causes increased reductant slip. For all three LNT, the $\mathrm{NH}_{3}$ selectivity shows a maximum at medium temperature $\left(200-250{ }^{\circ} \mathrm{C}\right)$. This is in line with current literature. The

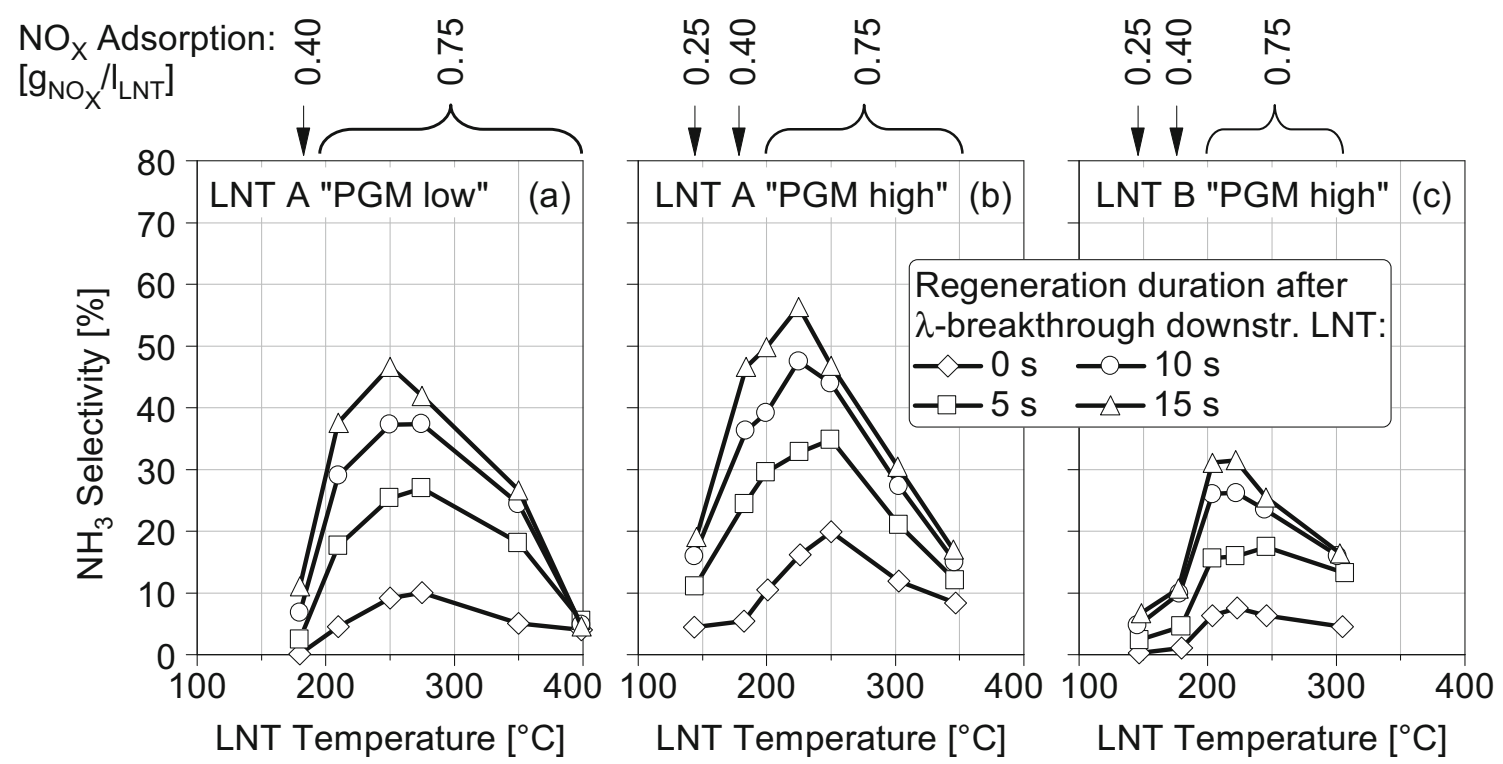

Fig. $8 \mathrm{NH}_{3}$ selectivity of LNT regeneration as function of LNT temperature for various regeneration durations after $\lambda$-breakthrough downstream of the LNT: a LNT A "PGM low", b LNT A "PGM high", c LNT B "PGM high" (reformate substitute dosing $=45 \mathrm{~g} / \mathrm{min}, \mathrm{SV}_{\mathrm{LNT}, \mathrm{Reg}}=3900 \mathrm{~h}^{-1}$ ) 
$\mathrm{NH}_{3}$ emission results basically from superposition of the intrinsic $\mathrm{NO}_{\mathrm{X}}$ reduction to $\mathrm{NH}_{3}$ and the in-catalyst $\mathrm{NH}_{3}$ re-oxidation. The reaction rate of both reactions increases with increasing temperature but forms a maximum profile due to different light-off temperatures. LNT A shows significantly higher $\mathrm{NH}_{3}$ selectivity compared to LNT B.

Finally, the influence of the $\mathrm{NO}_{\mathrm{X}}$ load on the $\mathrm{NH}_{3}$ formation and related parameters for various regeneration durations after $\lambda$-breakthrough are presented in at Fig. 9 at $250^{\circ} \mathrm{C}$.

The cumulated emitted $\mathrm{NH}_{3}$ quantity (Fig. 9a) steadily increases with increasing $\mathrm{NO}_{\mathrm{X}}$ load. A saturation of the $\mathrm{NH}_{3}$ emission is earlier reached for lower $\mathrm{NO}_{\mathrm{X}}$ load than at higher $\mathrm{NO}_{\mathrm{X}}$ load. This suggests a limited rate of nitrate decomposition and subsequent reduction to $\mathrm{NH}_{3}$. In contrast, except for short regeneration duration, the $\mathrm{NH}_{3}$ yield decreases with increasing $\mathrm{NO}_{\mathrm{X}}$ load. Either, more $\mathrm{NH}_{3}$ gets re-oxidized at higher $\mathrm{NO}_{\mathrm{X}}$ load or the increasing substrate temperature by the exothermic reductant conversion decreases the $\mathrm{NH}_{3}$ formation tendency. The increasing $\mathrm{NH}_{3}$ yield at short regeneration duration might be explained by the axial $\mathrm{NO}_{\mathrm{X}}$ load profile. With ongoing $\mathrm{NO}_{\mathrm{X}}$ adsorption, especially the local $\mathrm{NO}_{\mathrm{X}}$ load at the substrate outlet increases. According to the $\mathrm{NH}_{3}$ formation principle, with increasing $\mathrm{NO}_{\mathrm{X}}$ load at the rear part of the substrate, more $\mathrm{NO}_{\mathrm{X}}$ gets reduced to $\mathrm{NH}_{3}$ and less $\mathrm{NH}_{3}$ gets re-oxidized. However, the cyclic $\mathrm{NH}_{3} / \mathrm{NO}_{\mathrm{X}}$ ratio upstream of the SCR ( $\alpha_{\text {cyclic }}$ so-called feed ratio, Eq. 5) is more
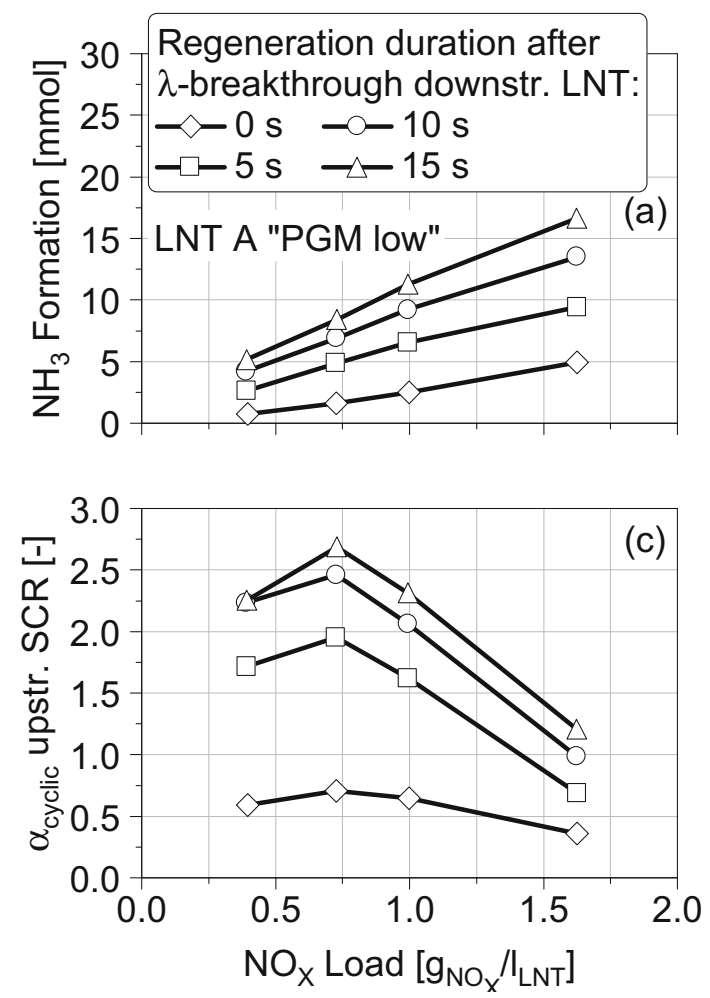

Fig. $9 \mathrm{NH}_{3}$ formation as function of $\mathrm{NO}_{\mathrm{X}}$ load and regeneration duration (displayed as duration after $\lambda$-breakthrough downstream of the LNT): a cumulated $\mathrm{NH}_{3}$ quantity, b $\mathrm{NH}_{3}$ yield, c cyclic $\mathrm{NH}_{3} / \mathrm{NO}_{\mathrm{X}}$ ratio $\left(\alpha_{\text {cyclic }}\right)$ relevant for the passive $\mathrm{SCR}$ operation than the single $\mathrm{NH}_{3}$ formation parameter. The $\mathrm{NO}_{\mathrm{X}}$ feed to the SCR increases with increasing $\mathrm{NO}_{\mathrm{X}}$ load due to the decreasing $\mathrm{NO}_{\mathrm{X}}$ adsorption efficiency. Moreover, uniquely for an LNT bypass concept, the $\mathrm{NO}_{\mathrm{X}}$ feed to the $\mathrm{SCR}$ is also related to the $\mathrm{NO}_{\mathrm{X}}$ slip due to the open LNT bypass. The latter can be limited by temporarily lowering the $\mathrm{NO}_{\mathrm{X}}$ engine out emission during the open bypass phase. Summarizing, the superposition of $\mathrm{NH}_{3}$ emission and $\mathrm{NO}_{\mathrm{X}}$ slip results in a maximum formation for $\alpha_{\text {cyclic }}$ upstream of the SCR. By relating the $\alpha_{\text {cyclic }}$ to the fuel economy penalty FEP (Eq. 6), a parameter can be defined, which provides an overall efficiency indication. The FEP declines with increasing adsorption duration but increases with increasing regeneration duration. Hence, the LNT regeneration strategy can be controlled either in terms of high $\mathrm{NH}_{3}$ emissions for fast SCR filling (maximum $\alpha_{\text {cyclic }}$ ) or in terms of best overall efficiency (maximum $\alpha_{\text {cyclic }} /$ FEP).

$A_{\text {cyclic }}=\left[\frac{\int\left(\dot{n}_{N H_{3}}\right)_{S C R \text { upstream }}}{\int\left(\dot{n}_{N O_{X}}\right)_{S C R \text { upstream }}}\right]_{\text {adsorption+regereneration }}$

$F E P=\frac{\int \dot{m}_{\text {Diesel fuel, } L N T \text { Regerneration }}}{\int \dot{m}_{\text {Diesel fuel, } \text { engine lean operation }}}$
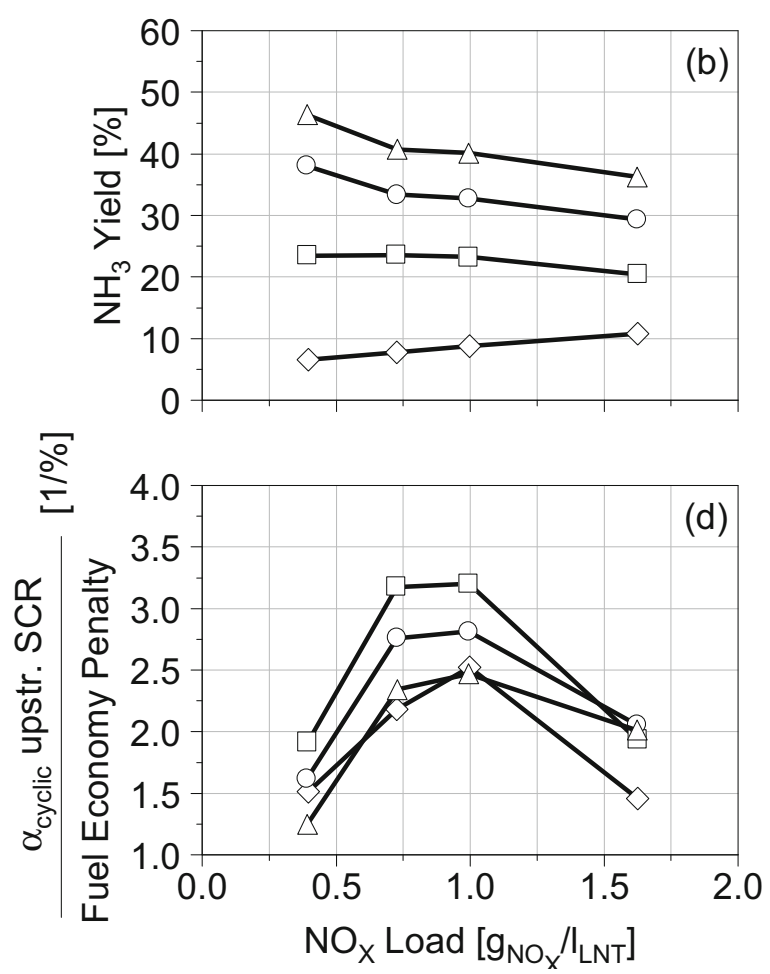

upstream of the SCR (usually called feed ratio), $\mathbf{d}$ ratio of $\alpha_{\text {cyclic }}$ to the fuel economy penalty (reformate substitute dosing $=45 \mathrm{~g} / \mathrm{min}$, $\mathrm{SV}_{\mathrm{LNT}, \text { Reg }}=3900 \mathrm{~h}^{-1}, T_{\mathrm{LNT}}=250^{\circ} \mathrm{C}, \mathrm{LNT}$ A "PGM low") 
The fuel economy penalty (FEP, Eq. 6) is defined by the ratio of additional diesel fuel injected into the reformer during LNT regeneration and the diesel fuel consumption of the engine. To minimize the $\mathrm{NO}_{\mathrm{X}}$ slip through the open bypass during the LNT regeneration, the engine is operated in a low $\mathrm{NO}_{\mathrm{X}}$ raw emission mode. In the applied extent, this engine mode switch had only negligible influence on the engine fuel consumption and hence on the fuel economy penalty.

\subsection{Steady-State LNT + SCR Investigation on Engine Test Bench}

An example of the $\mathrm{NO}_{\mathrm{X}}$ conversion behavior of the combined LNT + SCR system during cyclic adsorption-regeneration operation is shown in Fig. 10 for an LNT temperature of $250^{\circ} \mathrm{C}$. As shown in the upper diagram, after a short period with high LNT $\mathrm{NO}_{\mathrm{X}}$ adsorption efficiency, the $\mathrm{NO}_{\mathrm{X}}$ concentration downstream of the LNT is continuously increasing due to the increasing $\mathrm{LNT} \mathrm{NO}_{\mathrm{X}}$ load and hence lower $\mathrm{NO}_{\mathrm{X}}$ adsorption efficiency. However, the $\mathrm{NO}_{\mathrm{X}}$ tailpipe concentration is kept close to zero due to continuous $\mathrm{NO}_{\mathrm{X}}$ conversion by the passive SCR catalyst. The cumulated $\mathrm{NH}_{3}-\mathrm{NO}_{\mathrm{X}}$ ratio upstream of the SCR $\left(\alpha_{\text {cyclic }}\right)$ over the total $\mathrm{NO}_{\mathrm{X}}$ adsorption and regeneration cycle is slightly above 1 . For instance, the LNT and bypass $\mathrm{NO}_{\mathrm{X}}$ slip are more than equaled by the onboard $\mathrm{NH}_{3}$ formation during LNT regeneration. To minimize the $\mathrm{NO}_{\mathrm{X}}$ slip through the open bypass during the LNT regeneration, the engine is operated at lower $\mathrm{NO}_{\mathrm{X}}$ raw emission. The continuous $\alpha$ can reach temporarily high values (here» 50), which demands high $\mathrm{NH}_{3}$ adsorption efficiency of the passive SCR. In the given example, no $\mathrm{NH}_{3}$ slip downstream of the SCR was observed. Contrary to a conventional LNT application, the LNT $\mathrm{NO}_{\mathrm{X}}$ slip does not automatically drop the system $\mathrm{NO}_{\mathrm{X}}$ conversion but can be converted by the passive SCR. Therefore, the LNT $\mathrm{NO}_{\mathrm{X}}$ adsorption duration can be elongated, and the LNT can be operated at higher $\mathrm{NO}_{\mathrm{X}}$ storage levels resulting in a higher degree of material utilization. As shown in the bottom diagram, only the LNT is enriched locally during the rich LNT regeneration. Both the engine and the tailpipe flow path downstream of the recombination of main and bypass line are continuously operated at $\lambda>1$. The engine-independent LNT enrichment avoids the risk of engine oil dilution, which might be caused by engine internal late post injection. Additionally, drivability and acoustic drawbacks due to switch into rich engine operation can be avoided. Furthermore, the lean tailpipe exhaust gas composition offers the possibility to oxidize the occasional reductant slip during the LNT regeneration. Usually, the higher the space velocity (SV), the lower is the catalyst performance because of kinetic limitations especially at low temperature. As shown in the bottom diagram, the closed LNT flow path during LNT regeneration results in a significant drop of LNT space velocity, which offers the potential for increasing regeneration efficiency.

The dependency of the total $\mathrm{NO}_{\mathrm{X}}$ conversion and $\alpha_{\text {cyclic }}$ on the fuel economy penalty for various temperatures is discussed in Fig. 11. As shown before, with elongated regeneration duration and hence increasing fuel economy penalty, $\alpha_{\text {cyclic }}$ can be increased. The total $\mathrm{NO}_{\mathrm{X}}$ conversion also increases with increasing FEP, on the one hand due to the increased $\alpha_{\text {cyclic }}$ and on the other hand due to a higher LNT efficiency. The latter could be reached by either higher completion of LNT regeneration or higher $\mathrm{NO}_{\mathrm{X}}$ adsorption
Fig. $10 \mathrm{NO}_{\mathrm{X}}$ conversion behavior of LNT + SCR system in cyclic adsorption-regeneration operation as function of time (reformate substitute dosing $=45$ $\mathrm{g} / \mathrm{min}, \mathrm{SV}_{\mathrm{LNT}, \mathrm{Reg}}=3900 \mathrm{~h}^{-1}$, $T_{\mathrm{LNT}}=250^{\circ} \mathrm{C}, T_{\mathrm{SCR}}=225^{\circ} \mathrm{C}$, $\mathrm{FEP}=1.9 \%, \mathrm{SV}_{\mathrm{SCR}}=24,000 \mathrm{~h}^{-1}$, LNT A "PGM high")
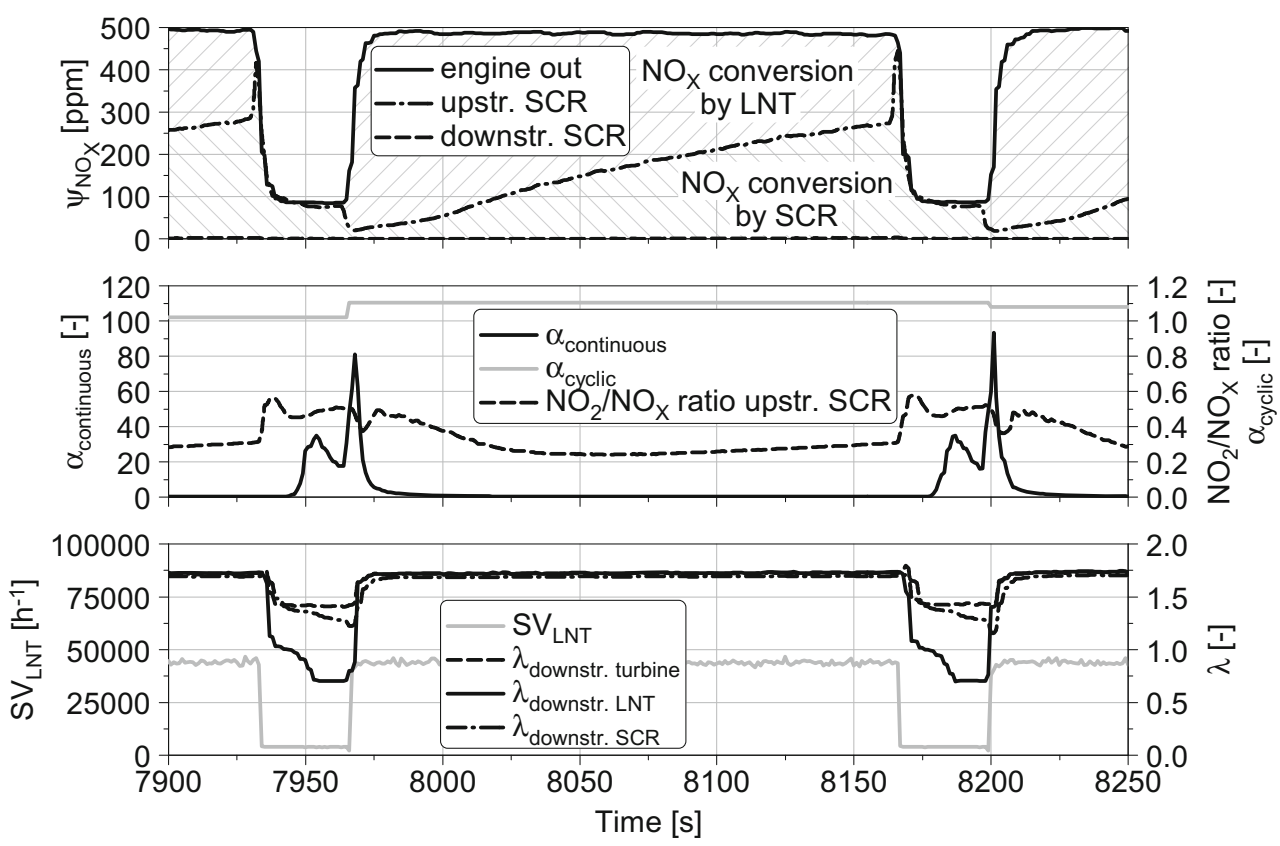


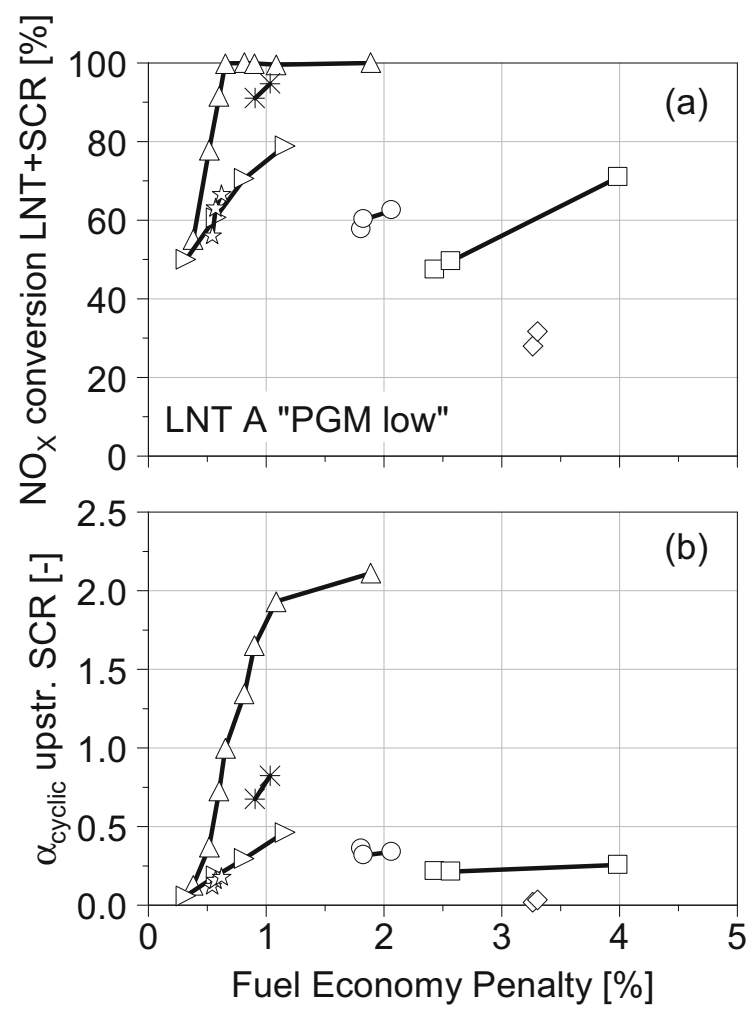

Fig. $11 \mathrm{NO}_{\mathrm{X}}$ conversion of the LNT + SCR system as function of fuel economy penalty at various temperatures in cyclic adsorptionregeneration operation: a cyclic total $\mathrm{NO}_{\mathrm{X}}$ conversion $(\mathrm{LNT}+\mathrm{SCR}), \mathbf{b}$

efficiency by operation at lower $\mathrm{NO}_{\mathrm{X}}$ load. Thus, $\mathrm{NO}_{\mathrm{X}}$ conversion and fuel consumption are directly linked. The already discussed strong temperature dependency of the $\mathrm{NH}_{3}$ formation results in large variation of maximum $\alpha_{\text {cyclic }}$ and hence also of the maximum total $\mathrm{NO}_{\mathrm{X}}$ conversion. As expected, the $\mathrm{NO}_{\mathrm{X}}$ conversion of the passive SCR solely depends on the feed ratio $\left(\alpha_{\text {cyclic }}\right)$.
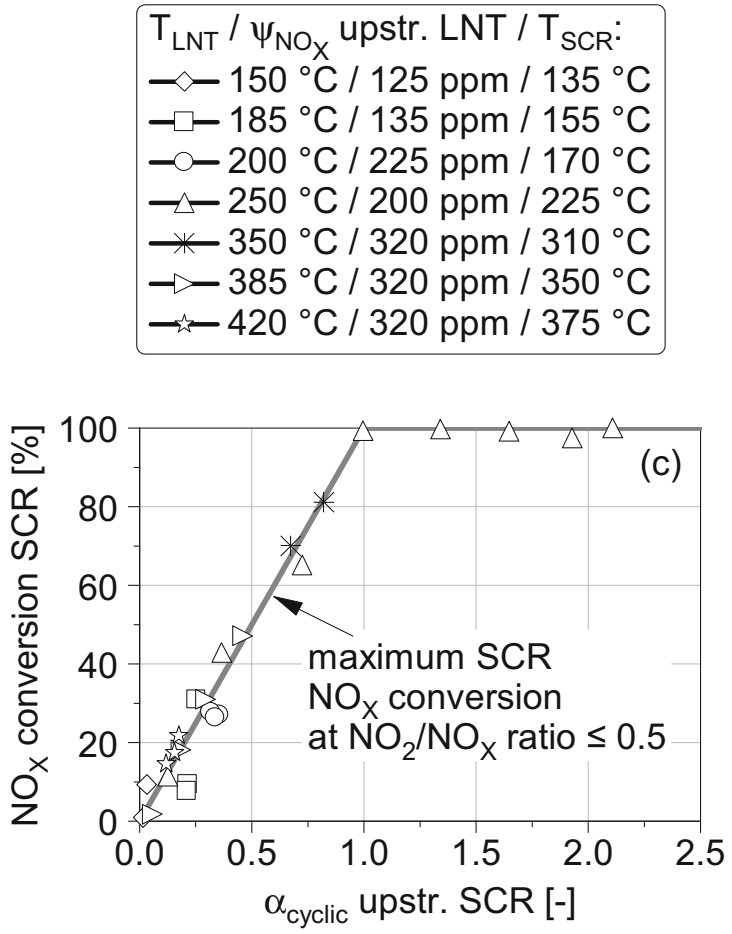

$\alpha_{\text {cyclic }}$ upstream of the SCR, $\mathrm{c}$ cyclic $\mathrm{NO}_{\mathrm{X}}$ conversion of the passive SCR as function of $\alpha_{\text {cyclic }}$ (reformate substitute dosing $=45 \mathrm{~g} / \mathrm{min}, \mathrm{SV}_{\mathrm{LNT}, \mathrm{Reg}}=$ $3900 \mathrm{~h}^{-1}$, LNT A "PGM low")

A significant influence on the total $\mathrm{NO}_{\mathrm{X}}$ performance and especially on the conversion share between LNT and SCR is given by the LNT $\mathrm{NO}_{\mathrm{X}}$ adsorption duration and therefore the LNT $\mathrm{NO}_{\mathrm{X}}$ load. In Fig. 12, the $\mathrm{NO}_{\mathrm{X}}$ conversion efficiencies, $\mathrm{NO}_{\mathrm{X}}$ conversion shares of LNT with bypass and passive SCR, and the related FEP are shown as function of LNT $\mathrm{NO}_{\mathrm{X}}$ load. Considering the boundary conditions of the discussed
Fig. $12 \mathrm{NO}_{\mathrm{X}}$ conversion efficiencies, related fuel economy penalty (FEP), and $\mathrm{NO}_{\mathrm{X}}$ conversion shares of LNT with bypass and passive SCR as function of LNT $\mathrm{NO}_{\mathrm{X}}$ load (reformate substitute dosing $=45$ $\mathrm{g} / \mathrm{min}, \mathrm{SV}_{\mathrm{LNT}, \text { Reg }}=3900 \mathrm{~h}^{-1}$, $\mathrm{T}_{\mathrm{LNT}}=250^{\circ} \mathrm{C}$, LNT A "PGM low")
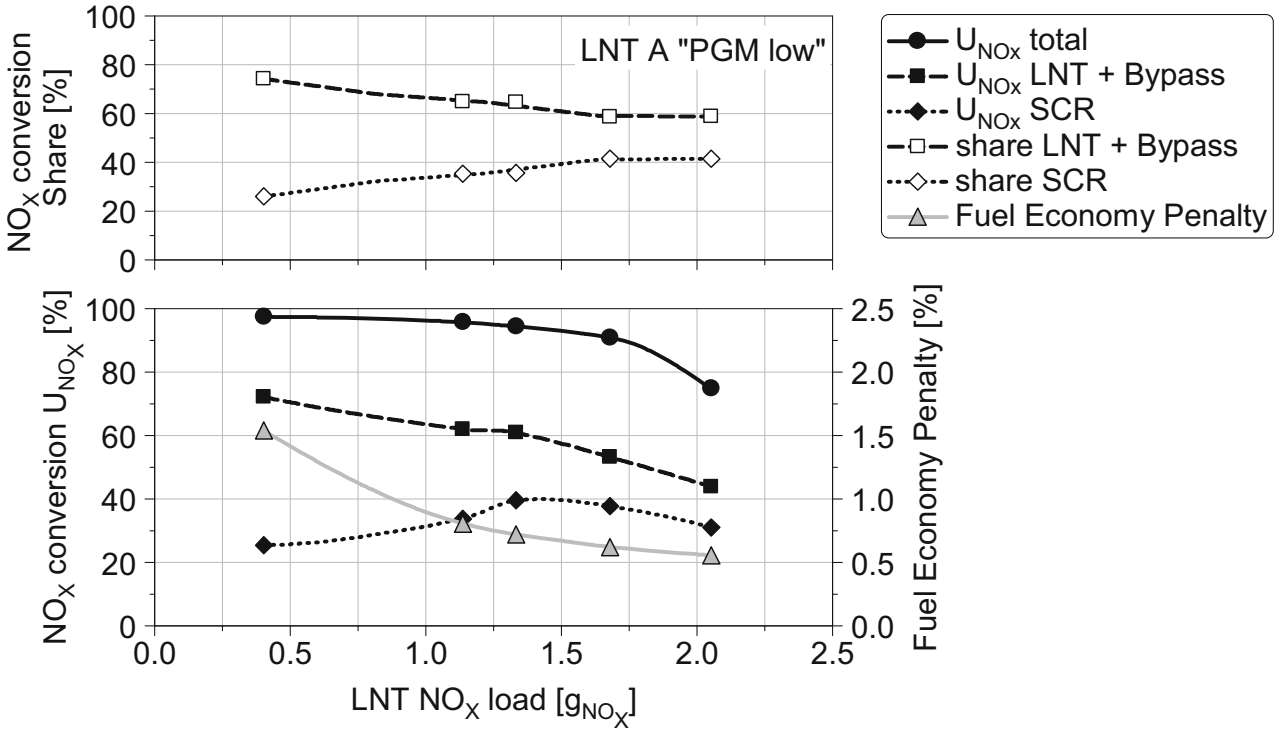
example in Fig. 12, the total $\mathrm{NO}_{\mathrm{X}}$ conversion is almost constant for the $\mathrm{NO}_{\mathrm{X}}$ load of 0.4-1.4 g. However, with elongating $\mathrm{NO}_{\mathrm{X}}$ adsorption duration and therefore increasing LNT $\mathrm{NO}_{\mathrm{X}}$ load, the $\mathrm{NO}_{\mathrm{X}}$ conversion distribution is significantly shifting from LNT to SCR. As shown in the bottom diagram, the loss of LNT conversion is almost compensated by the increasing SCR conversion, which achieves a maximum of $40 \%$. The $\mathrm{NO}_{\mathrm{X}}$ conversion share between LNT and SCR is changing from $75 / 25 \%$ at $0.4 \mathrm{~g} \mathrm{NO}_{\mathrm{X}}$ load to $60 / 40 \%$ at $1.4 \mathrm{~g} \mathrm{NO}_{\mathrm{X}}$ load. The increasing $\mathrm{NO}_{\mathrm{X}}$ slip through LNT and bypass for $\mathrm{NO}_{\mathrm{X}}$ adsorption durations up to the $\mathrm{NO}_{\mathrm{X}}$ load level of $1.4 \mathrm{~g}$ can be compensated by the $\mathrm{NH}_{3}$ formation on the LNT. $\alpha_{\text {cyclic }}$ upstream of the SCR is $\geq 1$ (not displayed) for $\mathrm{LNT} \mathrm{NO}_{\mathrm{X}}$ load below $1.4 \mathrm{~g}$. In case of $\mathrm{LNT} \mathrm{NO}_{\mathrm{X}}$ loads above $1.4 \mathrm{~g}, \alpha_{\text {cyclic }}$ is dropping below the stoichiometry of 1 , which results in corresponding decline of $\mathrm{SCR} \mathrm{NO}_{\mathrm{X}}$ conversion and therefore also of the total $\mathrm{NO}_{\mathrm{X}}$ conversion.

A great potential of the conversion shifting between LNT and SCR is the impact on the fuel economy penalty, shown in the bottom diagram of Fig. 12. By expanding the $\mathrm{NO}_{\mathrm{X}}$ adsorption duration toward higher $\mathrm{LNT} \mathrm{NO}_{\mathrm{X}}$ loads, the FEP can be lowered from $1.5 \%$ at $0.4 \mathrm{~g}$ to $0.75 \%$ at $1.4 \mathrm{~g}$. The higher the $\mathrm{NO}_{\mathrm{X}}$ load, the more reducing agent is consumed for $\mathrm{NO}_{\mathrm{X}}$ reduction. Reasons are the lower regeneration frequency as well as the higher $\mathrm{NH}_{\mathrm{X}}$ selectivity of the LNT regeneration (not displayed) for higher $\mathrm{NO}_{\mathrm{X}}$ loads. A further reason for the benefit of high $\mathrm{NO}_{\mathrm{X}}$ loads is caused by the OSC of the LNT which has to be reduced in parallel to the $\mathrm{NO}_{\mathrm{X}}$ reduction. The reducing agent amount, which is consumed by the OSC during the LNT regeneration, increases the fuel economy penalty without any $\mathrm{NO}_{\mathrm{X}}$ reduction. Assuming constant OSC, by increasing the $\mathrm{NO}_{\mathrm{X}}$ load, relatively more reducing species will be consumed by $\mathrm{NO}_{\mathrm{X}}$ than by OSC. The higher the $\mathrm{NO}_{\mathrm{X}}$ load, the more beneficial becomes the ratio of oxygen molar amount stored in barium nitrate to the sum of oxygen in barium nitrate and cerium oxide (OSC), resulting in decreasing FEP.
Figure 13 depicts the correlation of $\mathrm{NO}_{\mathrm{X}}$ conversion, fuel economy penalty, and $\mathrm{NO}_{\mathrm{X}}$ raw emission level for LNT-only and LNT + SCR at $230^{\circ} \mathrm{C}$. Generally, increasing $\mathrm{NO}_{\mathrm{X}}$ conversion progressively causes the drawback of increasing fuel consumption penalty. The $\mathrm{NO}_{\mathrm{X}}$ conversion converges asymptotically against a maximum. Furthermore, higher $\mathrm{NO}_{\mathrm{X}}$ raw emission shows significantly negative impact on $\mathrm{NO}_{\mathrm{X}}$ conversion for certain FEP and maximum achievable $\mathrm{NO}_{\mathrm{X}}$ conversion. Hence, for achieving high $\mathrm{NO}_{\mathrm{X}}$ conversion at reasonable fuel economy penalty, the $\mathrm{NO}_{\mathrm{X}}$ raw emission must be limited. In comparison to the LNT-only, the combined LNT+ passive SCR system shows high benefits regarding FEP and $\mathrm{NO}_{\mathrm{X}}$ conversion. In the given example, high maximum total $\mathrm{NO}_{\mathrm{X}}$ conversion of up to $>95 \%$ is achievable at low FEP of $\approx 1 \%$ for reasonable $\mathrm{NO}_{\mathrm{X}}$ raw emissions. At high $\mathrm{NO}_{\mathrm{X}}$ raw emission level, the total $\mathrm{NO}_{\mathrm{X}}$ conversion decreases but is significantly higher than for LNT-only. At a certain $\mathrm{NO}_{\mathrm{X}}$ conversion, significant lower FEP is attainable by the LNT + SCR.

Figure 14 shows the steady-state $\mathrm{NO}_{\mathrm{X}}$ conversion and fuel economy penalty of the combined LNT + passive SCR system for two system variants with onboard generated reformate and reformate substitute gas as function of LNT temperature. The attained $\mathrm{NO}_{\mathrm{X}}$ conversion is comparable for the operation with the integrated onboard reformer as well as for the operation with the bottled reformate substitute gas. The system with the higher PGM-loaded LNT achieves a slight increase in conversion at $T<250{ }^{\circ} \mathrm{C}$. At $250{ }^{\circ} \mathrm{C}$, almost complete conversion is achieved at FEP of $\approx 1.5 \%$. The operation strategy of $\mathrm{NO}_{\mathrm{X}}$ adsorption and regeneration is optimized with regard to maximum total $\mathrm{NO}_{\mathrm{X}}$ conversion and suitable fuel consumption penalty. The SCR significantly contributes to the total $\mathrm{NO}_{\mathrm{X}}$ conversion. At $T<250{ }^{\circ} \mathrm{C}$, the total steady-state $\mathrm{NO}_{\mathrm{X}}$ conversion drops caused by reduced LNT activity as well as $\mathrm{NH}_{3}$ yield. The FEP increases due to higher LNT regeneration frequency as well as lower engine fuel consumption due to lower engine load. Nevertheless, $65-70 \%$ steady-state $\mathrm{NO}_{\mathrm{X}}$ conversion at $185{ }^{\circ} \mathrm{C}$ and $30 \%$ steady-state $\mathrm{NO}_{\mathrm{X}}$ conversion at
Fig. 13 Correlation between $\mathrm{NO}_{\mathrm{X}}$ conversion and fuel economy penalty as function of $\mathrm{NO}_{\mathrm{X}}$ raw emission level: a LNTonly, b LNT + passive SCR (reformate substitute dosing $=45$ $\mathrm{g} / \mathrm{min}, \mathrm{SV}_{\mathrm{LNT}, \text { Reg }}=3900 \mathrm{~h}^{-1}$, $T_{\mathrm{LNT}}=230^{\circ} \mathrm{C}$, LNT A "PGM high")
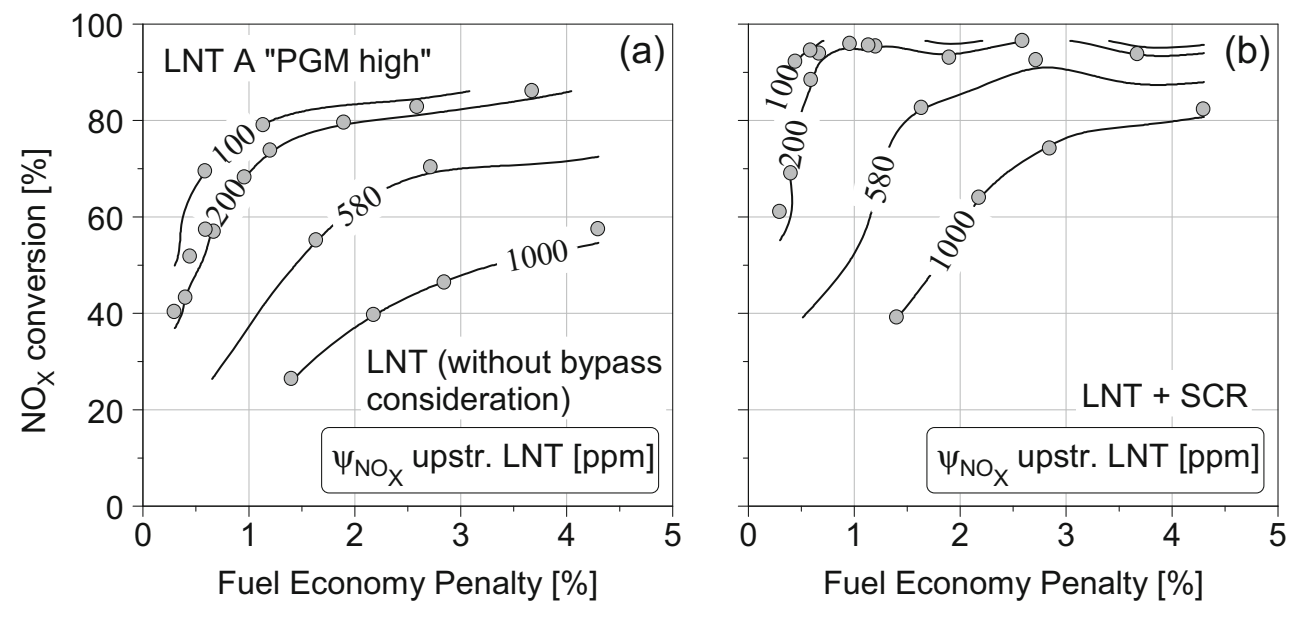
Fig. 14 Steady-state $\mathrm{NO}_{\mathrm{X}}$ conversion and fuel economy penalty of combined LNT + passive SCR system with reformate and reformate substitute gas as function of LNT temperature; EU4 $\mathrm{NO}_{\mathrm{X}}$ raw emission level (system 1: LNT A "PGM low"+SCR, system 2: LNT A "PGM high" + SCR)

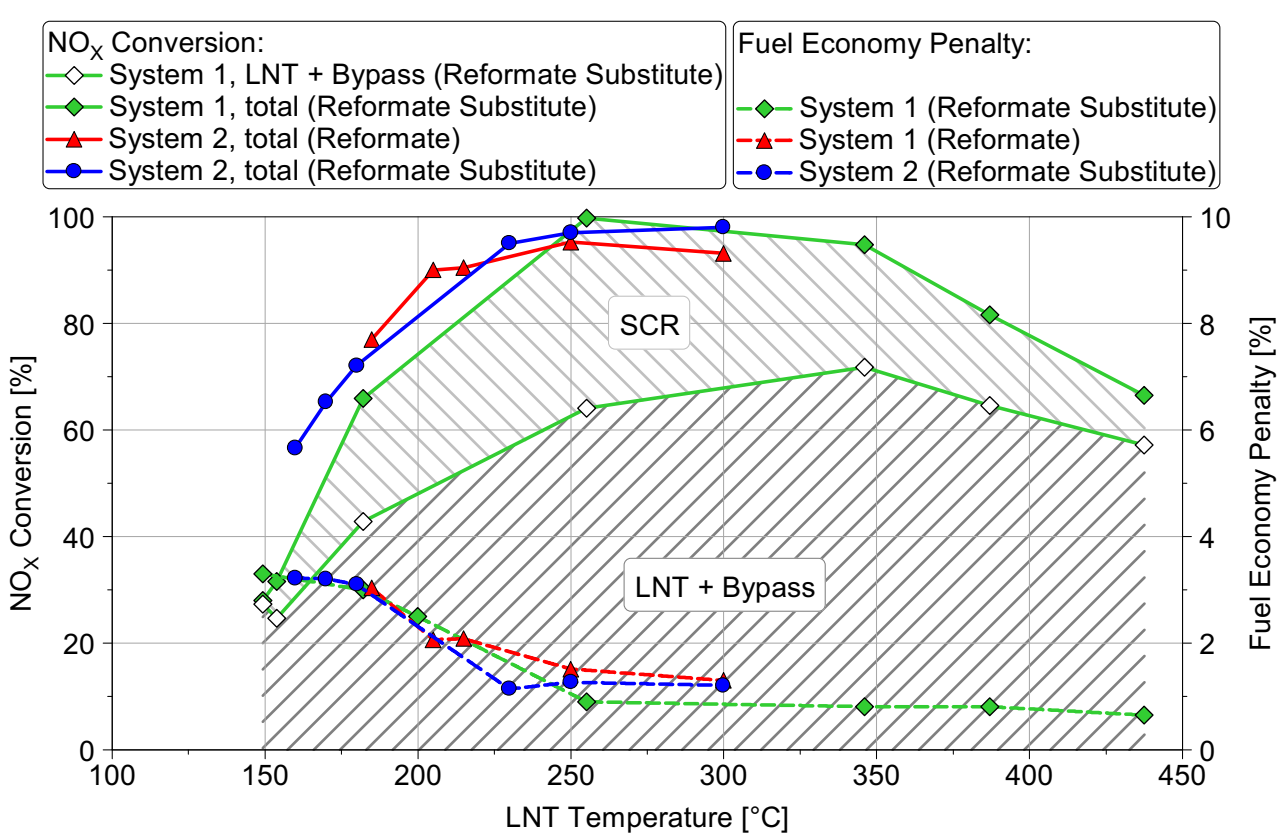

$150{ }^{\circ} \mathrm{C}$ are still achieved. In transient operation, higher conversion rates can be achieved due to pure $\mathrm{NO}_{\mathrm{X}}$ adsorption at the LNT as well as SCR conversion with previously stored $\mathrm{NH}_{3}$. At $T>350{ }^{\circ} \mathrm{C}$, the steady-state $\mathrm{NO}_{\mathrm{X}}$ conversion drops because of decreasing (for thermodynamic reasons) $\mathrm{NO}_{\mathrm{X}}$ adsorption capacity of the LNT as well as lower $\mathrm{NH}_{3}$ yield of the LNT regeneration. The decreased $\mathrm{LNT} \mathrm{NH}_{3}$ yield causes limited steady-state SCR conversion in contrast to urea-based SCR operation. However, during transient operation, complete conversion can still be maintained by the SCR for short time, e.g., during DPF regeneration, by consuming previously stored $\mathrm{NH}_{3}$ depending on SCR $\mathrm{NH}_{3}$ load and $\mathrm{NO}_{\mathrm{X}}$ mass flow. This represents high $\mathrm{NO}_{\mathrm{X}}$ performance benefits compared to conventional LNT application.
4.4 Transient LNT + SCR Investigation in Demonstrator Vehicle

Finally, Fig. 15 shows the final results for $\mathrm{NO}_{\mathrm{X}}$ conversion and fuel economy penalty (separated in FEP for heating and FEP for rich LNT regeneration) in all transient cycles measured in the demonstrator vehicle. The underfloor-positioned aftertreatment system requires significant fuel economy penalty by heating but only minor by LNT enrichment in the cold start cycles NEDC and WLTC. However, in real driving with longer warm operation periods, the system performance shows high $\mathrm{NO}_{\mathrm{X}}$ conversion and realizes low $\mathrm{NO}_{\mathrm{X}}$ emission at low fuel economy penalty of less than $2 \%$. The fuel
Fig. 15 Summary of transient $\mathrm{NO}_{\mathrm{X}}$ conversion and fuel economy penalty of combined LNT + passive SCR system (operation with reformate substitute gas, LNT A "PGM high", vehicle weight differing to inertia weight class due to additional equipment and passengers)
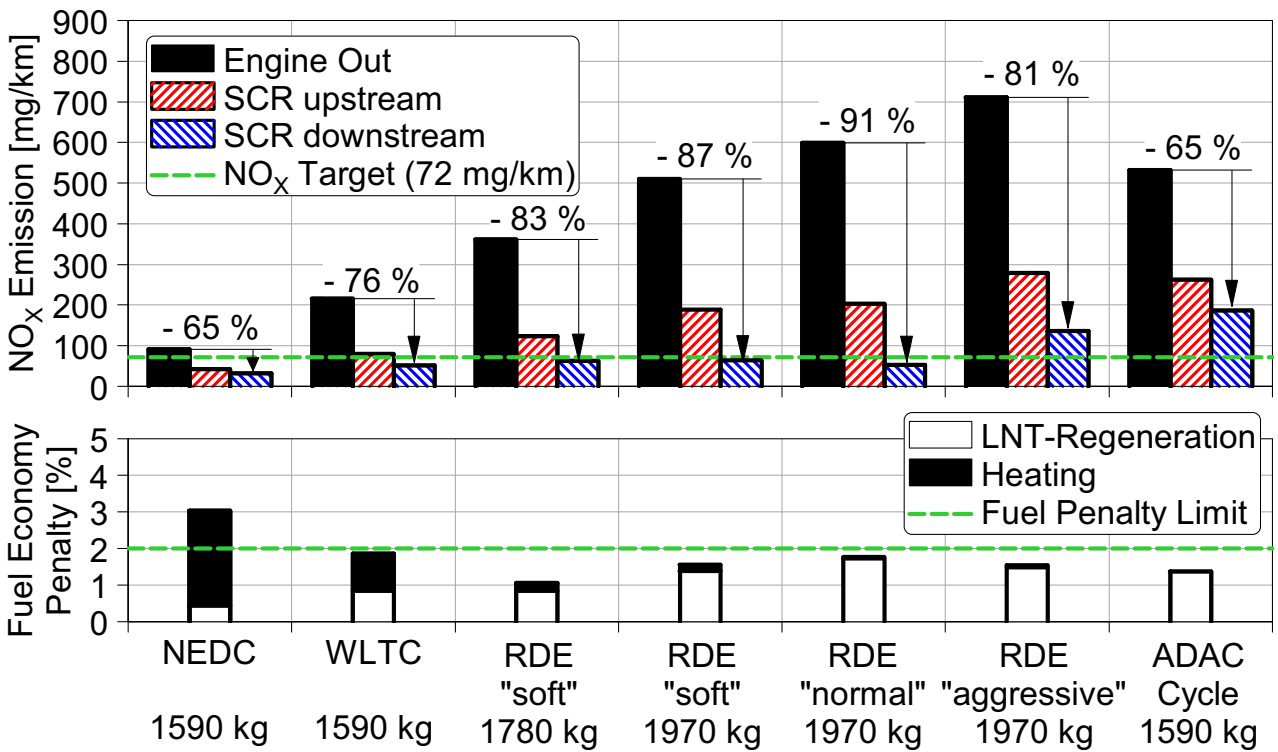
economy penalty is generally low compared to conventional engine internal enrichment, due to higher reductant formation efficiency of the reforming approach. The passive SCR can significantly contribute to the total $\mathrm{NO}_{\mathrm{X}}$ conversion. The high $\mathrm{NO}_{\mathrm{X}}$ raw emissions and exhaust temperature during aggressive driving are challenging for the LNT-based system with only passive SCR due to the $\mathrm{LNT} \mathrm{NO}_{\mathrm{X}}$ conversion drop at high temperature. Additionally, high space velocity caused by high engine speed results on one hand in limited $\mathrm{NO}_{\mathrm{X}}$ adsorption efficiency on the LNT. On the other hand, it causes fast consumption of SCR $\mathrm{NH}_{3}$ load due to LNT $\mathrm{NO}_{\mathrm{X}}$ breakthrough. However, especially under these conditions, the underfloor position is beneficial compared to a close-coupled position and enables maximum $\mathrm{NO}_{\mathrm{X}}$ conversion for operating without active urea dosing. Summarizing, a clear trade-off between short cold cycles and long hot driving is obvious.

\section{Summary and Conclusions}

The upcoming emission legislation requires emission control for the complete exhaust temperature range from cold start up to high temperature operation in real dynamic testing procedures. This is challenging especially for the $\mathrm{NO}_{\mathrm{X}}$ treatment. Both currently used $\mathrm{NO}_{\mathrm{X}}$ reduction systems, LNT and SCR, provide optimum reduction efficiency at a specific temperature range only. A combination of both systems with active application (LNT with frequent rich regeneration, SCR with urea dosing) is promising but will probably request urea refilling by the customer as well as $\mathrm{CO}_{2}$ emission drawback due to fuel economy penalty caused by the LNT regeneration. As an alternative approach, the combination of LNT and passive SCR using $\mathrm{NH}_{3}$ produced by $\mathrm{NO}_{\mathrm{X}}$ reduction on the LNT was investigated. Furthermore, the LNT reduction was performed in LNT bypass operation with onboard fuel reformate gas $\left(\mathrm{H}_{2}+\mathrm{CO}\right)$ at low space velocity in order to enhance the $\mathrm{NO}_{\mathrm{X}}$ conversion efficiency especially at low temperature and minimize the fuel economy penalty of the reduction process.

The $\mathrm{NH}_{3}$ formation by the LNT $\mathrm{NO}_{\mathrm{X}}$ reduction causes discontinuous $\mathrm{NH}_{3}$ supply to the SCR. Due to the $\mathrm{NH}_{3}$ formation characteristic of the LNT, the optimum temperature window for steady-state operation for the passive SCR approach is in the range of $200-300{ }^{\circ} \mathrm{C}$. At lower temperature, the LNT adsorption and regeneration efficiencies decrease due to kinetic reasons. At higher temperature, the $\mathrm{NO}_{\mathrm{X}}$ adsorption capacity of the LNT decreases due to thermodynamic reasons. Additionally, the $\mathrm{NH}_{3}$ formation becomes negligible so that the passive SCR does not reach the high efficiency of an active SCR. The combined LNT and passive SCR system achieves nearly $100 \% \mathrm{NO}_{\mathrm{X}}$ conversion efficiency at $250{ }^{\circ} \mathrm{C}$ with fuel economy penalty of $1.5 \%$ for Euro $4 \mathrm{NO}_{\mathrm{X}}$ raw emission level. Caused by high $\mathrm{NH}_{3}$ selectivity of up to approx. $50 \%$ regarding the $\mathrm{LNT} \mathrm{NO}_{\mathrm{X}}$ load, the passive SCR contributes with up to $35 \%$ significantly to the total $\mathrm{NO}_{\mathrm{X}}$ conversion. At an exhaust temperature of $175^{\circ} \mathrm{C}$, the $\mathrm{NO}_{\mathrm{X}}$ conversion efficiency of approx. $40 \%$ by the LNT can still be increased up to $60 \%$ by the combined passive SCR.

The reduction of the fuel penalty was caused primarily by two different measures. The $\mathrm{NH}_{3}$ production on the LNT offers an LNT operation at higher $\mathrm{NO}_{\mathrm{X}}$ load due to the conversion of $\mathrm{LNT} \mathrm{NO}_{\mathrm{X}}$ breakthrough by the passive SCR. The higher $\mathrm{NO}_{\mathrm{X}}$ load leads to a reduced regeneration frequency. At high $\mathrm{NO}_{\mathrm{X}}$ load, relatively more fuel reacts with $\mathrm{NO}_{\mathrm{X}}$ instead of OSC. Hence, the fuel efficiency could be increased compared to a conventional LNT application. Additional improvement of fuel economy might be achieved by using LNT with lower OSC due to no necessity of $\mathrm{NH}_{3}$ formation prevention on the LNT. Further, the fuel economy penalty was reduced significantly by the use of an engine-independent LNT regeneration with reformate gas in bypass operation. Compared to diesel engine enrichment, the reducing agent generation by fuel reforming is more efficient.

Regarding the vehicle integration of the aftertreatment system, especially the LNT position in a passive SCR combination is crucial. In short cold start cycles, a close-coupled position is favorable because of faster heat-up. However, in contrast to the current technical trend, in longer warm operation in real driving, an underfloor position becomes favorable due to taking the full potential of the passive SCR approach.

Summarizing, in comparison to conventional LNT application, a combined system of LNT in bypass operation with passive SCR improves the $\mathrm{NO}_{\mathrm{X}}$ performance at lower fuel economy penalty and represents an attractive approach for future emission aftertreatment. While LNT and passive SCR combinations already reached commercial maturity, relevant practical topics like OBD and complexity need more investigations for the reformer itself.

Acknowledgments The research leading to these results has received funding from the European Union 7th Framework Program [FP7/20072011] under grant agreement no. 234032. The authors are grateful to the funding of EU in the POWERFUL research project and all persons, who know to have their contribution in this study.

The authors would also like to thank Volkswagen $A G$ for the vehicle measurements and Dinex Ecocat for the catalyst supply.

Furthermore, the authors would like to thank the $D F G$ for enabling this work by funding the mass spectrometer measurement devices.

Parts of this work are the result of the successful cooperation with RWTH's Center for Automotive Catalytic Systems Aachen (ACA).

\section{References}

1. Satoh N, Ohno H, Nakatsuji $\mathrm{T}$ (2006) $\mathrm{A} \mathrm{NO}_{\mathrm{X}}$ reduction system using ammonia storage-selective catalytic reduction in rich and lean operations. Paper presented at the 15th Aachen Colloquium Automobile and Engine Technology, RWTH Aachen University, Aachen, 9-11 October 2006 
2. Liu, Y., Harold, M.P., Luss, D.: Coupled $\mathrm{NO}_{\mathrm{X}}$ storage and reduction and selective catalytic reduction using dual-layer monolithic catalysts. Appl Catal B Environ 121-122, 239-251 (2012). doi:10. 1016/j.apcatb.2012.04.013

3. Liu, Y., Zheng, Y., Harold, M.P., Luss, D.: Lean $\mathrm{NO}_{\mathrm{X}}$ reduction on LNT-SCR dual-layer catalysts by $\mathrm{H}_{2}$ and CO. Appl Catal B Environ 132-133, 293-303 (2013). doi:10.1016/j.apcatb.2012.10.034

4. Liu, Y., Zheng, Y., Harold, M.P., Luss, D.: Lean $\mathrm{NO}_{\mathrm{X}}$ reduction with $\mathrm{H}_{2}$ and $\mathrm{CO}$ in dual-layer LNT-SCR monolithic catalysts: impact of ceria loading. Top Catal 56, 104-108 (2013). doi:10.1007/s11244013-9936-1

5. Zheng, Y., Liu, Y., Harold, M.P., Luss, D.: LNT-SCR dual-layer catalysts optimized for lean $\mathrm{NO}_{\mathrm{X}}$ reduction by $\mathrm{H}_{2}$ and $\mathrm{CO}$. Appl Catal B Environ 148-149, 311-321 (2014). doi:10.1016/j.apcatb. 2013.11.007

6. Theis JR, Dearth M, McCabe R (2011) LNT + SCR catalyst systems optimized for $\mathrm{NO}_{\mathrm{X}}$ conversion on diesel applications. SAE 2011-010305

7. Waldbüßer $\mathrm{N}$ : $\mathrm{NO}_{\mathrm{X}}$-Minderung am Pkw-Dieselmotor mit einem Kombinationssystem zur Abgasnachbehandlung. Dissertation, University of Kaiserlautern (2005)

8. Weibel, M., Waldbüßer, N., Wunsch, R., Chatterjee, D., BandlKonrad, B., Krutzsch, B.: A novel approach to catalysis for $\mathrm{NO}_{\mathrm{X}}$ reduction in diesel exhaust gas. Top Catal 52, 1702-1708 (2009). doi:10.1007/s11244-009-9329-7

9. Chatterjee, D., Kočí, P., Schmeißer, V., Marek, M., Weibel, M., Krutzsch, B.: Modelling of a combined $\mathrm{NO}_{\mathrm{X}}$ storage and $\mathrm{NH}_{3}$-SCR catalytic system for diesel exhaust gas aftertreatment. Catal Today 151, 395-409 (2010). doi:10.1016/j.cattod.2010.01.014

10. Snow R, Cavatatio G, Dobson D, Montreuil C, Hammerle R: Calibration of a LNT-SCR diesel aftertreatment system. SAE 200701-1244 (2007)

11. Xu L, McCabe R, Ruona W, Cavataio G: Impact of a Cu-zeolite SCR catalyst on the performance of a diesel LNT + SCR system. SAE 2009-01-0285 (2009)

12. Theis JR, Ura J, McCabe R: The effects of sulfur poisoning and desulfation temperature on the $\mathrm{NO}_{\mathrm{X}}$ conversion of LNT + SCR systems for diesel applications. SAE 2010-01-0300 (2010)

13. Xu L, McCabe R, Dearth M, Ruona W: Laboratory and vehicle demonstration of "2nd-generation" LNT + in-situ SCR diesel $\mathrm{NO}_{\mathrm{X}}$ emission control systems. SAE 2010-01-0305 (2010)

14. Xu L, McCabe R, Tennison P, Jen HW: Laboratory and vehicle demonstration of "2nd-generation" LNT + in-situ SCR diesel emission control systems. SAE 2011-01-0308 (2011)

15. Li W, Perry KL, Narayanaswamy K, Kim CH, Najt P: Passive ammonia SCR system for lean-burn SIDI engines. SAE 2010-01-0366 (2010)

16. Kim CH, Perry K, Viola M, Li W, Narayanaswamy K: Three-way catalyst design for urealess passive ammonia SCR: lean-burn SIDI aftertreatment system. SAE 2011-01-0306 (2011)

17. Weirich $\mathrm{M}$ : $\mathrm{NO}_{\mathrm{X}}$-Reduzierung mit Hilfe des SCR-Verfahrens am Ottomotor mit Direkteinspritzung. Dissertation, University of Kaiserlautern (2001)

18. McCarthy J: Fuel reformer, LNT and SCR Aftertreatment system meeting emissions useful life requirements. Paper presented at the Directions in Engine-Efficiency and Emissions Research (DEER) Conference, Dearborn, 3-6 August 2009 (2009)

19. Poojary D, Nicole J, McCarthy J, Yang H: Improved system performance and reduced cost of a fuel reformer, LNT, and SCR aftertreatment system meeting emissions useful life requirement. Paper presented at the Directions in Engine-Efficiency and Emissions Research (DEER) Conference, Detroit, 27-30 September 2010 (2010)

20. McCarthy J, Yue Y, Mahakul B, Gui X, Yang H, Ngan E, Price K: Meeting Nonroad Final Tier 4 Emissions on a 4045 John Deere engine using a fuel reformer and LNT system with an optional SCR showing transparent vehicle operation, Vehicle Packaging and Compliance to End-of-Life Emissions. SAE 2011-01-2206 (2011)

21. Kupe J, Zizelman J, Botti JJ, Simpkins H, Hemingway MD, LaBarge WJ, Silvis TW, Kirwan JE, Bonadies J, Price K: System and method of NOx abatement. Delphi Technologies Inc. Patent US 2006/0213187 A1, 28 September 2006 (2006)

22. Hemingway MD, Christopher BJ, Thornton MP: Engine exhaust emission control system providing on-board ammonia generation. Delphi Technologies Inc. Patent US 2007/0271908 A1, 29November 2007 (2007)

23. Kupe J, Bosch R, Bonadies J, Kirwan J: Demonstration of a fuel reformer system for meeting future diesel vehicle low emission standards. Paper presented at the 15th Aachen Colloquium Automobile and Engine Technology, RWTH Aachen University, Aachen, 9-11 October 2006 (2006)

24. Beckmann T, Massner A: Internal combustion engine provided with an exhaust gas cleaning system and method for cleaning exhaust gases of an internal combustion engine. DaimlerChrysler AG. Patent WO 2005/049984 A1, 02 June 2005 (2005)

25. Hu H, Stover T: Hybrid catalyst system for exhaust emissions reduction. Eaton Corporation. Patent WO 2006/008625 A1, 26 January 2006 (2006)

26. Clayton, R.D., Harold, M.P., Balakotaiah, V.: Selective catalytic reduction of $\mathrm{NO}$ by $\mathrm{H}_{2}$ in $\mathrm{O}_{2}$ on $\mathrm{Pt} / \mathrm{BaO} / \mathrm{Al}_{2} \mathrm{O}_{3}$ monolith $\mathrm{NO}_{\mathrm{X}}$ storage catalysts. Appl Catal B Environ 81, 161-181 (2008). doi:10.1016/j. apcatb.2007.11.038

27. Kouakou, A., Dhainaut, F., Granger, P., Fresnet, F., Louis-Rose, I.: Study of ammonia formation during the purge of a lean $\mathrm{NO}_{\mathrm{X}}$ trap. Top Catal 52, 1734-1739 (2009). doi:10.1007/s11244-009-9343-9

28. Larson RS, Chakravarthy VK, Pihl JA, Daw CS: Modeling chemistry in lean $\mathrm{NO}_{\mathrm{X}}$ traps under reducing conditions. SAE 2006-01-3446 (2006)

29. van Hardeveld, R.M., van Santen, R.A., Niemantsverdriet, J.W.: Kinetics and mechanism of $\mathrm{NH}_{3}$ formation by the hydrogenation of atomic nitrogen on $\mathrm{Rh}(111)$. J Phys Chem B 101, 998-1005 (1997). doi:10.1021/jp963022

30. Cant, N.W., Chambers, D.C., Liu, I.O.Y.: The Reduction of NO by $\mathrm{CO}$ in the presence of water vapour on supported platinum catalysts: formation of isocyanic acid (HNCO) and ammonia. Appl Catal B Environ 46, 551-559 (2003). doi:10.1016/S0926-3373(03)00318-7

31. Neyertz, C., Volpe, M., Perez, D., Costilla, I., Sanchez, M., Gigola, C.: NO reduction with $\mathrm{CO}$ in the presence and absence of $\mathrm{H}_{2} \mathrm{O}$ over $\mathrm{Pd} / \gamma-\mathrm{Al}_{2} \mathrm{O}_{3}$ and $\mathrm{Pd}-\mathrm{VO}_{\mathrm{X}} / \gamma-\mathrm{Al}_{2} \mathrm{O}_{3}$ catalysts: The formation of $\mathrm{HNCO}, \mathrm{NH}_{3}$ and stable surface species. Appl Catal A Gen 368, 146-157 (2009). doi:10.1016/j.apcata.2009.08.023

32. Szailer, T., Kwak, J.H., Kim, D.H., Hanson, J.C., Peden, C.H.F., Szanyi, J.: Reduction of stored $\mathrm{NO}_{\mathrm{X}}$ on $\mathrm{Pt} / \mathrm{Al}_{2} \mathrm{O}_{3}$ and $\mathrm{Pt} / \mathrm{BaO}$ / $\mathrm{Al}_{2} \mathrm{O}_{3}$ catalysts with $\mathrm{H}_{2}$ and CO. J Catal 239, 51-64 (2006). doi: 10.1016/j.jcat.2006.01.014

33. Mulla, S.S., Chaugule, S.S., Yezerets, A., Currier, N.W., Delgass, W.N., Ribeiro, F.H.: Regeneration mechanism of $\mathrm{Pt} / \mathrm{BaO} / \mathrm{Al}_{2} \mathrm{O}_{3}$ lean $\mathrm{NO}_{\mathrm{X}}$ trap catalyst with $\mathrm{H}_{2}$. Catal Today 136, 136-145 (2008). doi:10. 1016/j.cattod.2008.01.007

34. Pihl JA, Parks II JE, Daw CS, Root TW: Product selectivity during regeneration of lean $\mathrm{NO}_{\mathrm{X}}$ trap catalysts. SAE 2006-01-3441 (2006)

35. Lietti, L., Nova, I., Forzatti, P.: Role of ammonia in the reduction by hydrogen of $\mathrm{NO}_{\mathrm{X}}$ stored over $\mathrm{Pt}-\mathrm{Ba} / \mathrm{Al}_{2} \mathrm{O}_{3}$ lean $\mathrm{NO}_{\mathrm{X}}$ trap catalysts. $\mathrm{J}$ Catal 257, 270-282 (2008). doi:10.1016/j.jcat.2008.05.005

36. Kočí, P., Plát, F., Štěpánek, J., Kubíček, M., Marek, M.: Dynamics and selectivity of $\mathrm{NO}_{\mathrm{X}}$ reduction in $\mathrm{NO}_{\mathrm{X}}$ storage catalytic monolith. Catal Today 137, 253-260 (2008). doi:10.1016/j.cattod.2007.11.023

37. Clayton, R.D., Harold, M.P., Balakotaiah, V.: $\mathrm{NO}_{\mathrm{X}}$ storage and reduction with $\mathrm{H}_{2}$ on $\mathrm{Pt} / \mathrm{BaO} / \mathrm{Al}_{2} \mathrm{O}_{3}$ monolith: Spatio-temporal resolution of product distribution. Appl Catal B Environ 84, 616-630 (2008). doi:10.1016/j.apcatb.2008.05.018 
38. Bhatia, D., Clayton, R.D., Harold, M.P., Balakotaiah, V.: A global kinetic model for $\mathrm{NO}_{\mathrm{X}}$ storage and reduction on $\mathrm{Pt} / \mathrm{BaO} / \mathrm{Al}_{2} \mathrm{O}_{3}$ monolithic catalysts. Catal Today 147S, 250-256 (2009). doi:10. 1016/j.cattod.2009.07.024

39. Partridge, W.P., Choi, J.-S.: $\mathrm{NH}_{3}$ formation and utilization in regeneration of $\mathrm{Pt} / \mathrm{Ba} / \mathrm{Al}_{2} \mathrm{O}_{3} \mathrm{NO}_{\mathrm{X}}$ storage-reduction catalyst with $\mathrm{H}_{2}$. Appl Catal B Environ 91, 144-151 (2009). doi:10.1016/j.apcatb.2009.05. 017

40. Clayton, R.D., Harold, M.P., Balakotaiah, V., Wan, C.Z.: Pt dispersion effects during $\mathrm{NO}_{\mathrm{X}}$ storage and reduction on $\mathrm{Pt} / \mathrm{BaO} / \mathrm{Al}_{2} \mathrm{O}_{3}$ catalysts. Appl Catal B Environ 90, 662-676 (2009). doi:10.1016/j. apcatb.2009.04.029

41. Abdulhamid, H., Fridell, E., Skoglundh, M.: The reduction phase in $\mathrm{NO}_{\mathrm{X}}$ storage catalysis: Effect of type of precious metal and reducing agent. Appl Catal B Environ 62, 319-328 (2006). doi:10.1016/j. apcatb.2005.08.014

42. Okumura, K., Motohiro, T., Sakamoto, Y., Shinjoh, H.: Effect of combination of noble metals and metal oxide supports on catalytic reduction of $\mathrm{NO}$ by $\mathrm{H}_{2}$. Surf Sci 603, 2544-2550 (2009). doi:10. 1016/j.susc.2009.05.031

43. Cant, N.W., Chambers, D.C., Liu, I.O.Y.: The formation of isocyanic acid during the reaction of $\mathrm{NH}_{3}$ with $\mathrm{NO}$ and excess $\mathrm{CO}$ over silicasupported platinum, palladium, and rhodium. J Catal 231, 201-212 (2005). doi:10.1016/j.jcat.2005.01.022

44. Chen H-Y, Weigert E, Fedeyko J, Cox J, Andersen P: Advanced catalysts for combined (NAC+SCR) emission control systems. SAE 2010-01-0302 (2010)

45. Bhatia, D., Harold, M.P., Balakotaiah, V.: Modeling the effect of Pt dispersion and temperature during anaerobic regeneration of a lean $\mathrm{NO}_{\mathrm{X}}$ trap catalyst. Catal Today 151, 314-329 (2010). doi:10.1016/j. cattod.2010.02.055

46. Maeda, N., Urakawa, A., Baiker, A.: Influence of Pt-Ba-proximity on $\mathrm{NO}_{\mathrm{X}}$ storage-reduction mechanisms: a space- and time-resolved in situ infrared spectroscopy study. Top Catal 52, 1746-1751 (2009). doi:10.1007/s11244-009-9342-x

47. Ji, Y., Choi, J.-S., Toops, T.J., Crocker, M., Naseri, M.: Influence of ceria on the $\mathrm{NO}_{\mathrm{X}}$ storage/reduction behavior of lean $\mathrm{NO}_{\mathrm{X}}$ trap catalysts. Catal Today 136, 146-155 (2008). doi:10.1016/j.cattod.2007. 11.059
48. Le Phuc, N., Corbos, E.C., Courtois, X., Can, F., Marecot, P., Duprez, D.: $\mathrm{NO}_{\mathrm{X}}$ storage and reduction properties of $\mathrm{Pt} / \mathrm{Ce}_{\mathrm{x}} \mathrm{Zr}_{1-\mathrm{x}} \mathrm{O}_{2}$ mixed oxides: Sulfur resistance and regeneration, and ammonia formation. Appl Catal B Environ 93, 12-21 (2009). doi:10.1016/j.apcatb.2009. 09.007

49. Choi J-S, Pihl J, Partridge B, Chakravarthy K, Toops T, Daw S: Factors affecting $\mathrm{LNT} \mathrm{NH}_{3}$ selectivity. Paper presented at the DOE Crosscut Workshop on Lean Emissions Reduction Simulation (CLEERS) Conference, University of Michigan, Dearborn, 20-22 April 2010 (2010)

50. Choi, J.-S., Partridge, W.P., Daw, C.S.: Sulfur impact on $\mathrm{NO}_{\mathrm{X}}$ storage, oxygen storage, and ammonia breakthrough during cyclic lean/rich operation of a commercial lean $\mathrm{NO}_{\mathrm{X}}$ trap. Appl Catal B Environ 77, 145-156 (2007). doi:10.1016/j.apcatb.2007.07.025

51. Castoldi, L., Lietti, L., Forzatti, P., Morandi, S., Ghiotti, G., Vindigni, F.: The $\mathrm{NO}_{\mathrm{X}}$ storage-reduction on $\mathrm{Pt}-\mathrm{K} / \mathrm{Al}_{2} \mathrm{O}_{3}$ Lean $\mathrm{NO}_{\mathrm{X}}$ Trap catalyst. J Catal 276, 335-350 (2010). doi:10.1016/j.jcat.2010.09.026

52. Nova, I., Lietti, L., Forzatti, P.: Mechanistic aspects of the reduction of stored $\mathrm{NO}_{\mathrm{X}}$ over $\mathrm{Pt}-\mathrm{Ba} / \mathrm{Al}_{2} \mathrm{O}_{3}$ lean $\mathrm{NO}_{\mathrm{X}}$ trap systems. Catal Today 136, 128-135 (2008). doi:10.1016/j.cattod.2008.01.006

53. Maßner A: Stickoxidminderung bei Diesel-Nutzfahrzeugen mittels Kombination von $\mathrm{NO}_{\mathrm{X}}$-Speicherkatalysator und SCR-Katalysator. Dissertation, University of Stuttgart (2006)

54. Kočí, P., Plát, F., Štěpánek, J., Bártová, Š., Marek, M., Kubíček, M., Schmeißer, V., Chatterjee, D., Weibel, M.: Global kinetic model for the regeneration of $\mathrm{NO}_{\mathrm{X}}$ storage catalyst with $\mathrm{CO}, \mathrm{H}_{2}$ and $\mathrm{C}_{3} \mathrm{H}_{6}$ in the presence of $\mathrm{CO}_{2}$ and $\mathrm{H}_{2} \mathrm{O}$. Catal Today 147S, 257-264 (2009). doi: 10.1016/j.cattod.2009.07.036

55. Harbi, M., Epling, W.S.: The effects of regeneration-phase $\mathrm{CO}$ and/or $\mathrm{H}_{2}$ amount on the performance of a $\mathrm{NO}_{\mathrm{X}}$ storage/reduction catalyst. Appl Catal B Environ 89, 315-325 (2009). doi:10.1016/j.apcatb. 2008.12.010

56. Clayton, R.D., Harold, M.P., Balakotaiah, V.: Performance features of $\mathrm{Pt} / \mathrm{BaO}$ lean $\mathrm{NO}_{\mathrm{X}}$ trap with hydrogen as reductant. Am Inst Chem Eng 55, 687-700 (2009). doi:10.1002/aic. 11710

57. AL-Harbi, M., Epling, W.S.: Effects of different regeneration timing protocols on the performance of a model $\mathrm{NO}_{\mathrm{X}}$ storage/reduction catalyst. Catal Today 151, 347-353 (2010). doi:10.1016/j.cattod.2009. 12.004 